University of California, Hastings College of the Law UC Hastings Scholarship Repository

Faculty Scholarship

1992

\title{
Reconciling Individual Rights and Government Interests: Madisonian Principles Versus Supreme Court Practice
}

David L. Faigman

UC Hastings College of the Law, faigmand@uchastings.edu

Follow this and additional works at: http://repository.uchastings.edu/faculty_scholarship

\section{Recommended Citation}

David L. Faigman, Reconciling Individual Rights and Government Interests: Madisonian Principles Versus Supreme Court Practice, 78 Va. L. Rev. 1521 (1992).

Available at: http://repository.uchastings.edu/faculty_scholarship/869 


\title{
UNIVERSITY of CALIFORNIA HASTINGS COLLEGE OF THE LAW
}

\section{Faculty Publications}

UC Hastings College of the Law Library

\author{
Author: $\quad$ David L. Faigman \\ Source: $\quad$ Virginia Law Review \\ Citation: $\quad 78$ VA. L. ReV. 1521 (1992). \\ Title: $\quad$ Reconciling Individual Rights and Government Interests: Madisonian Principles \\ Versus Supreme Court Practice
}

Originally published in VIRGINIA LAW REVIEW. This article is reprinted with permission from VIRGINIA LAW REVIEW and University of Virginia School of Law. 


\title{
RECONCILING INDIVIDUAL RIGHTS AND GOVERNMENT INTERESTS: MADISONIAN PRINCIPLES VERSUS SUPREME COURT PRACTICE
}

\author{
David L. Faigman*
}

INTRODUCTION

I. The TRAdITIONAL VIEW OF INTERPRETATION AND

APPLICATION IN CONSTITUTIONAL ADJUDICATION .... 1525

A. Madisonian Premises ..................... 1526

B. The Components of the Madisonian Model ......... 1529

1. The Definition Prong: Identifying Individual Rights ............................. 1530

2. The Application Prong: Assessing Government Interests........................... 1531

3. Definition Meets Application: Reconciling Individual Rights and Government Interests .... 1534

II. Turning Madison on His Head ................ 1539

A. An Introductory Exemplar: Defining the "Free Exercise of Religion" ...................... 1540

B. Reconciling Individual Rights and Government Interests Along the Spectrum of Constitutional Methods............................... 1547

1. Category Definition ..................... 1547

a. Defining "Liberty" and "Property" ......... 1548

b. Defining "Cruel and Unusual Punishment".. 1551

2. Definitional Balancing: Defining Speech ........ 1555

3. Multitiered Balancing Tests ................ 1563

a. The Equal Protection Clause ............. 1563

b. The Due Process Clause ................ 1566

4. Ad Hoc Balancing ...................... 1571

a. Procedural Due Process ................ 1572

* Associate Professor of Law, University of California, Hastings College of the Law.

I owe a considerable debt of gratitude to my many colleagues who commented on early drafts of this Article. Particularly deserving of my thanks are Evan Lee, John Monahan, Calvin Massey, Eileen Scallen and Scott Sundby, for being generous with their time and ideas. Also, many thanks to Emily Prescott and Dana Hayter for their excellent research assistance. 
b. The Fourth Amendment................ 1574

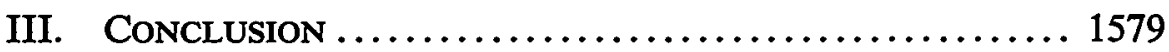

Yet, if so keen your zeal to know

In brief the tale of Troy's last woe,

Though memory shrinks with backward start,

And sends a shudder to my heart,

I take the word.

... A giant horse uprear,

And with compacted beams of pine

The texture of its ribs entwine. ...

There in the monster's cavernous side

Huge frames of chosen chiefs they hide,

And steel-clad soldiery finds room

Within that death-producing womb.

\section{INTRODUCTION}

TO general constitutional principle is so accepted in theory yet so 1 often violated in practice than that the Bill of Rights is a bulwark against majority tyranny. In theory, the Bill of Rights shields particular spheres of human affairs froin majoritarian intercession. It follows that these protected spheres should not be the subject of inajoritarian definition. ${ }^{2}$ Contrary to theory, however, the Bill of Rights is not such an invulnerable fortress.

The threshold question in constitutional adjudication is whether a constitutional right is inphicated. The answer to this question determines whether and to what degree the Umited States Supreme Court reviews challenged state action. If the Constitution encoinpasses the

1 The Aeneid of Virgil 38 (John Conington trans., 1900).

2 Justice Robert $H$. Jackson made this point eloquently:

The very purpose of a Bill of Rights was to withdraw certain subjects from the vicissitudes of political controversy, to place them beyond the reach of majorities and officials and to establish them as legal principles to be applied by the courts. One's right to life, liberty, and property, to free speech, a free press, freedom of worship and assembly, and other fundainental rights may not be subinitted to vote; they depend on the outcome of no elections.

West Virginia State Bd. of Educ. v. Barnette, 319 U.S. 624, 638 (1943); see also Barron v. Mayor \& City Council, 32 U.S. (7 Pet.) 243, 247-51 (1833) (asserting that Bill of Rights protects people froun the federal government's power); 1 Annals of Cong. 448-59 (Joseph Gales, Sr., ed., 1834) (discussing the purpose of the Bill of Rights). 
asserted right, the state should have to justify any abridgment of that right. If no constitutional right is involved, however, sound principles of deinocracy counsel deference to the inajority will. Constitutional analysis thus consists of two stages in the abstract: the first is a inatter of defining the Constitution to determine if it apphies; the second is a inatter of applying the Constitution to the instant case under whatever standard of review is dictated by the first part of the analysis. ${ }^{3}$ Upon close examination, however, it turns out that in practice these parts are not highly differentiated. Matters of application regularly intrude into questions of definition. The searcli for the ineaning of the constitutional text often includes a review of the government interests at stake. Because tlie thresliold question regarding tlie existence of constitutional riglits lias becoine infected witli the government's countervailing interests, those individual rights have lost mucl of their vitality, if not tlieir very existence.

As a practical inatter, the defimition prong determines who must bear the "burden of proof" or tle "burden of persuasion" in the application stage, and how lieavy that burden will be. ${ }^{4}$ It is cominonly believed, inoreover, that the standard of review tlie Court chooses when defining the Constitution preordains the outcoine when applying the Constitution: the party bearing the burden of persuasion usually loses. ${ }^{5}$ Thus, the Court's failure to separate definition froin application in constitutional interpretation lias a profound effect on constitutional discourse. Under conventional doctrine, wlien the Constitution is inplicated, the state bears the burden of deinonstrat-

3 Professor Schauer makes this distinction between definition and application in the First Amendment context by distinguishing between coverage and protection: "It is especially important ... to distinguish between activities that are within the scope of the first amendment and those that are not, and at the same time to distinguish between coverage and protection." Frederick Schauer, Speech and "Speech"-Obscerity and "Obscenity": An Exercise in the Interpretation of Constitutional Language, 67 Geo. L.J. 899, 905 (1979).

4 Throughout this Article I use the term "burden of persuasion" rather than "burden of proof" to describe the allocation of responsibility for demonstrating issues of constitutional concern between the parties. See infra notes 13-14 and accompanying text for further discussion of this issue. In addition, I purposely leave this term rather ambiguous because the Court uses the term loosely in its constitutional theory and in its constitutional practice, and because an attempt to fully develop the concept in constitutional adjudication would require an article in itself.

5 As Professor Gunther first observed regarding the standard of strict scrutiny, the standard is " 'strict' in theory and fatal in fact." Gerald Gunther, Foreword: In Search of Evolving Doctrine on a Changing Court: A Model For a Newer Equal Protection, 86 Harv. L. Rev. 1, 8 (1972). 
ing the state interests that justify infringing on those constitutional rights, as well as the empirical link between those ends and its chosen means. By inoving the analysis of government interests into the definition prong, the Court effectively reverses the allocation of the burdens for demonstrating the empirical basis supporting the government's asserted interests. Now the challenger of the state action inust shoulder the burden of refuting the state's interests to convince the Court that it should find, as an initial matter, that a constitutional right is implicated. Whether government interest analysis is treated within constitutional definition or apphication, therefore, frames and inevitably affects the course of constitutional adjudication.

Several coininentators have noted the Court's practice of shifting governinent interest analysis from the application prong into the definition prong in particular areas of the Constitution. ${ }^{6}$ This Article illustrates how the Court employs this strategy throughout the Constitution, and it challenges the practice of using government interests at the rights definition stage as contrary to the fundamental operating assuinptions of the Constitution. The Court's corruption of the

6 In a recent article, Professor Laurence Tribe and Michael Dorf criticized Justice Antonin Scalia for relying on government purposes in the process of defining the liberty right at stake in Michael H. v. Gerald D., 491 U.S. 110, 124 n.4 (1989). They reniarked on the effect of this view:

When we autonatically incorporate the factors that provide the state's possible justifications for its regulation into the initial definition of a liberty, the fundaniental nature of that liberty nearly vanishes. Unless the state's interest is facially absurd, when it is suitably incorporated into an asserted liberty it will render that liberty so specific as to seen insupportable .... At a minimun, the privacy right protected in Roe beconies the implausible "right" to destroy a living fetus. If one takes footnote 4 to its logical linit in the interpretation of enumerated rights, then the free speech right protected in New York Times Co. v Sullivan beconies the dubious "right" to libel a public official, and the right to an exclusionary renedy protected in Mapp $v$ Ohio beconies the counterintuitive "right" of a criminal to suppress the truth. To state these cases this way is to decide them in the goverument's favor. . . . Under Justice Scalia's footnote 4 approach ... the state interest obliterates, without explanation and at the outset, any trace of the individual liberty at stake.

Lawrence H. Tribe and Michael C. Dorf, Levels of Generality in the Definition of Rights, 57 U. Chi. L. Rev. 1057, 1096-97 (1990) (footnotes omitted).

Other comnientators who have noted the use of governnent interest analysis in rights definition include Professor Monaghan, discussed infra at notes 95, 98, 102, 104 and accompanying text (using government purposes to limit the definitional scope of the Due Process Clause) and Professor Ely, discussed infra at note 114 and acconpanying text (using government purposes to define "cruel and unusual" in the Eighth Amendmènt). 
Madisonian paradigm permits it selectively to avoid answering difficult empirical questions inherent in government imterest analysis. Government interests, like the forces besieging the city of Troy, have infiltrated the bulwark of the Bill of Rights through deception rather than superior force.

This Article is divided into two Sections. Section I explores the philosophical premises of the Constitution, which I refer to as the Madisomian paradigm, as they relate to the generally accepted interplay of the definition and apphication prongs. The classical view considers these prongs to be independent. This assumption of independence underlies the choice of methodologies the Court employs when it applies the Constitution to particular cases. In addition, Section I reviews the authorities traditionally relied upon to interpret the Constitution and, in order to place government interests analysis in context, outlines the manifold kinds of factfinding that attend constitutional adjudication. This Section concludes by examining the various inethods the Court uses to reconcile constitutional rights and government interests.

Section II canvasses the Court's inodern practice of defining and applying the Constitution. This review demonstrates that the processes of defimition and application are not so neatly compartmentalized as traditional theory describes them. The Court regularly construes the Constitution with an eye, sometimes both eyes, on how the various definitional choices will be applied. This Section also explores the ways that the tacit inixing of definition and application invert the fundamental premises of the Constitution's structure, subverting the capacity to hold the Court accountable for its decisions. By shifting the placement of government interest analysis, the Court subtly but profoundly manipulates the course of constitutional discourse. This veiled manipulation reduces the apphication prong to an undifferentiated and unverifiable extension of the definition prong. Definition and application merge, while still the Court speaks of them as separate.

\section{The Traditional View of Interpretation AND APPLICATION IN CONSTITUTIONAL ADJUDICATION}

Constitutional adjudication proceeds on the basis of a small set of fundamental operating assumptions. These assumptions reflect the delicate accommodation inherent in the Constitution between majoritarian will and individual liberty that the Court's constitutional 
jurisprudence undertakes to honor. The Court must respect the constitutional power of the majority, yet zealously guard against the use of this power to violate constitutional rights; the Court must understand the basis for the majority's actions, yet never forget the reasons the framers restricted the majority's power to act. This Section first examines the philosophical middle course the framers navigated between majoritarian power and the individual's right to be free of this power, and then this Section reviews the structure of analysis the Court brings to this journey.

\section{A. Madisonian Premises}

The process of allocating "burdens of persuasion" according to whether the Constitution is imphicated responds to the perceived fundamental contradiction endemic to the American political system. In what has been termed the Madisonian dilemma, ${ }^{7}$ the Constitution establishes a political structure that juxtaposes one fundamental principle, that of majority rule, with the contrary fundamental principle that individuals enjoy certain freedoms inviolate from the power of the majority. ${ }^{8}$ Judge Robert Bork described the resulting clash:

Majority tyranny occurs if legislation invades the areas properly left to individual freedom. Minority tyranny occurs if the majority is prevented from ruling where its power is legitimate. Yet, quite obviously, neither the majority nor the ininority can be trusted to define the freedom of the other. This dilemma is resolved in constitutional theory, and in popular understanding, by the Supreme Court's power to define both majority and minority freedom through the interpretation of the Constitution. ${ }^{9}$

7 Robert H. Bork, Neutral Principles and Some First Amendment Problems, 47 Ind. L.J. 1, 3 (1971); see also Robert A. Dahl, A Preface to Democratic Theory 22-24 (1956) (discussing the operational meaning of "tyranny" in reconciling the dilemma).

8 See generally Hugo L. Black, The Bill of Rights, 35 N.Y.U. L. Rev. 865, 867 (1960), stating:

The historical and practical purposes of a Bill of Rights, the very use of a written constitution, indigenous to America, the language the Framers used, the kind of threedepartment government they took pains to set up, all point to the creation of a government which was denied all power to do some things under any and all circumstances, and all power to do other things except precisely in the manner prescribed.

9 Bork, supra note 7, at 3; see also Robert H. Bork, The Tempting of America 39-41 (1990) (expanding on the theme of the Madisonian dilemma). Madison probably would not have fully shared Bork's description of the constitutional clash between the majority and the 
The Court's role in resolving the Madisonian dilemma brings about what Alexander Bickel termed the "counter-majoritarian difficulty." The Court's role is "difficult" because judicial review permits unelected judges to substitute their views of the Constitution's provisions for those of popularly elected representatives. ${ }^{11}$ Professor John Hart Ely summarized the difficulty concisely: "[A] body that is not elected or otherwise pohtically responsible in any significant way is telling the people's elected representatives that they cannot govern as they'd like."12 The counter-majoritarian difficulty renders suspicious too close judicial scrutiny of majoritarian action or too much sohitude of individual rights. Because of the primacy of this view, in the judicial context, the majoritarian principle is privileged above the possible presence of individual rights. ${ }^{13}$ This prioritizing of fundamental

minority. Madison's specific concern with minority tyranny was not that the minority would prevent a majority from ruling, but rather that a minority faction would legislate to the detriment of a majority. Madison dismissed this concern with his usual dispatch: "If a faction consists of less than a majority, relief is supplied by the republican principle, which enables the majority to defeat its sinister views by regular vote." The Federalist No. 10, at 80 (James Madison) (Mentor ed., 1961). Because Madison did not accept the contemporary view of judicial review, it is not surprising that he did not contemplate the gloss Bork has placed on his argument. For a more aceurate description of Madison's own resolution of the dilemma, see Robert J. Morgan, James Madison on the Constitution and the Bill of Rights 196 (1988) (quoting Madison: "[T] he 'true and safe construction' [of the Constitution would come from the] 'uniform sanction of successive legislative bodies; through a period of years and under the varied ascendancy of parties." " (quoting 3 James Madison, Letters and Other Writings of James Madison 228 (New York, Worthington 1884)); see also Dahl, supra note 7, at 23-24 (discussing possible definitions of "tyranny" within Madison's system). Still, Bork's modern interpretation probably conforms to the "popular understanding" of the clash, and it serves as a convenient vessel to explain the shifting burdens of persuasion in constitutional adjudication.

10 Alexander M. Bickel, The Least Dangerous Branch 16 (1962); see also id. at 1-23 (discussing the dilemma); John H. Ely, Democracy and Distrust: A Theory of Judicial Review $1-9$ (1980) (discussing the dilemma in terms of "interpretivism" by the Court).

11 See Bickel, supra note 10, at 34-37. Paraphrasing and agreeing with James Bradley Thayer, Bickel observed: "[E]very action of the other departments embodies an implicit decision on their part that it was within their constitutional power to act as they did. The judiciary must accord the utmost respect to this determination, even though it be a tacit one." Id. at 35 .

12 Ely, supra note 10 , at 4-5.

13 The relationship between the popularly elected branches of government and the unelected federal judiciary is undergoing considerable revision in the latest academic writings. In particular, the heretofore generally accepted "majoritarian paradigm"-i.e., the primacy of majoritarian decisionmaking-is being reconsidered. See, e.g., Erwin Chemerinsky, Foreword: The Vanishing Constitution, 103 Harv. L. Rev. 43 (1989) (criticizing the Rehnquist court's deference to the majoritarian values of the elected branches); Stephen M. Griffin, What is Constitutional Theory? The Newer Theory and the Decline of the Learned Tradition, $62 \mathrm{~S}$. 
principles gives rise to the shifting burdens in constitutional adjudication. Because this majoritarian perspective imparts a presumptive validity to state action, ${ }^{14}$ the challenger of this action bears the initial burden of persuading the Court that, in this case, an individual right is being infringed. The specific purposes that motivated the action in question are not pertinent at this poimt. Once a challenger is successful in establishing the existence of a constitutional right, however, the Court intercedes to review the majority's actions under a level of scrutiny that varies with the perceived importance of the right. This review brings into focus, for the first time, the specific reasons supporting the government's action.

The conventional view incorporating shifting burdens of persuasion rests on the inherent assumption that constitutional interpretations are derived independently of matters of constitutional apphication. ${ }^{15}$ Fundamental to the American system is the belief that constitutional rights are recognizable independently of the desires of the majority. As Professor Robert A. Dahl explamed, to allow the majority to decide "whether the punishing of some specified act would or would not be tyrannical . . . is precisely what Madison meant to prevent, and moreover would make the concept of majority tyranny meaningless." 16 The meaning of the Constitution derives from factors outside of the will of the inajority. If the Constitution operates as a bulwark against majority tyranny, the majority's reasons for acting cannot define what actions constitute tyranny. The majority's intentions

Cal. L. Rev. 493, 506-14 (1989) (arguing that the realist theory of democracy, which assumes the primacy of majoritarian decisionmaking, is simplistic and should be reconsidered); Lawrence G. Sager, The Incorrigible Constitution, 65 N.Y.U. L. Rev. 893 (1990) (arguing that the paradigm of "popular sovereignty" cannot be reconciled with our constitutional tradition, and that we should abandon that effort and recognize the promise of the tradition we have built). Central to the present thesis is the assumption that constitutional adjudication rests squarely within the majoritarian paradigm. Commentators who question this paradigm do not doubt its ascendancy, only its correctness. See Chemerinsky, supra, at 61. At bottom, I too question its correctness, but I leave such doubts for another day.

14 See City of Cleburne v. Cleburne Living Center, 473 U.S. 432, 440 (1985) ("The general rule is that legislation is presumed to be valid and will be sustained if the classification drawn by the statute is rationally related to a legitimate state interest.")

15 See Joln Monahan \& Laurens Walker, Empirical Questions Witlout Empirical Answers, 1991 Wis. L. Rev. 569, 582-87 (criticizing the Court's use of "burdens of proof" in constitutional challenges without reference to how the "rigltt" is defined).

16 Dalıl, supra note 7, at 24 . 
become relevant only subsequent to the determination of an individual constitutional right.

\section{B. The Components of the Madisonian Model}

As conventionally understood, the Court ascertains the appropriate level of review of government action through its reading of the Constitution. This review ranges from the extremely rare circumstance when the right is deemed "absolute" and no government purpose will justify its infringement to a variety of shding scale tests and balancing strategies that allow the government to override less fundainental rights with inuch less justification. ${ }^{17}$ This interpretation is primarily norinative, ${ }^{18}$ though it has significant empirical aspects. ${ }^{19}$ The Court's subsequent review of government interests at the apphication stage also has both a value coinponent and an empirical component, though at this stage the latter has soinewhat greater significance. The value component of constitutional application concerns the purpose of the government action, whereas the empirical coinponent concerns the adequacy of the action to the accomphishment of the purpose. ${ }^{20} \mathrm{It}$ should be emphasized that the respective values of the definition and application stages are distinct. When defining the Constitution, the guiding values come from the diverse constitutional authorities deinarcating the contours of individual hiberty; when applying the Constitution, the guiding values come, exphicitly or implicitly, from the inajoritarian forces responsible for the challenged action.

17 This relativistic perspective has meant that the government bears the burden to justify infringements of deeply perceived rights, whereas a challenger bears a continuing burden in regard to government imterference with rights of shallower dimensions. See Monahan \& Walker, supra note 15 , at 582-89.

18 See generally Michael J. Perry, Morality, Pohtics, and Law $121-79$ (1988) (exploring the relationship between morality and constitutional interpretation).

19 For a discussion of the einpirical components of the interpretation prong, see David L. Faigman, "Nornative Constitutional Fact-Finding": Exploring the Einpirical Component of Constitutional Interpretation, 139 U. Pa. L. Rev. 541 (1991).

20 The Court's statement of the rational basis test in United States v. Carolene Products, 304 U.S. 144, 152-54 (1938) illustrates the essentially factual nature of the test:

[R]egulatory legislation affecting ordmary commercial transactions is not to be pronounced unconstitutional unless in the light of the facts made known or generally assumed it is of such a character as to preclude the assumption that it rests upon some rational basis ....

... [Our inquiry] must be restricted to the issue whether any state of facts either known or which could reasonably be assumed affords support for it.

Id. 


\section{The Definition Prong: Identifying Individual Rights}

For most scholars, the definition prong represents the sum and substance of constitutional law. In the last thirty years, the volume of scholarly commentary on constitutional theory has vastly increased. ${ }^{21}$ This prodigious literature seeks to identify the boundaries, if any, on the legitimate exercise of the Court's interpretive powers. ${ }^{22}$ Stated simply, the Court and the commentators overwhelmingly seek the meaning of the-Constitution. ${ }^{23}$

Broken down into its constituent parts, the definition prong of constitutional interpretation consists of two queries. The first and threshold question asks whether the Constitution is implicated at all; the second asks how deeply the Constitution is imphcated-in other words, how "fundamental" the right is. ${ }^{24}$ The principal criterion for answering these questions is the constitutional text. Commentators agree, however, that the text alone cannot provide determinate answers to the sundry questions put to it. ${ }^{25}$ With varying degrees of agreement, a number of supplemental authorities have been accepted

21 See Griffin, supra note 13, at 493-94 nn.3-4; see generally Laurence E. Wiseman, The New Supreme Court Commentators: The Principled, the Political and the Philosophical, 10 Hastings Const. L.Q. 315 (1983) (discussing old and new constitutional theory and the views of various commentators).

22 See Frederick Schauer, Easy Cases, 58 S. Cal. L. Rev. 399, 399 (1985) ("In one way or another, virtually every constitutional theorist deems it primarily important to address the same question: where should we go in search of guiding principles for interpreting the linguistically open-ended clauses of the Constitution .... .") (footnote omitted).

${ }^{23}$ See Michael J. Perry, The Constitution, the Courts, and Human Rights: An Inquiry into the Legitimacy of Constitutional Policymaking by the Judiciary 10 (1982)

[I]nterpretive review . . . ascertains the constitutionality of a given policy choice by reference to one of the value judgments of which the Constitution consists-that is, by reference to a value judgment embodied, though not necessarily explicitly, either in some particular provision of the text of the Constitution or in the overall structure of government ordained by the Constitution."

Id. (emphasis omitted).

24 These two questions are often not separated clearly, but the second logically follows only from an affirmative answer to the first.

25 Professor Leonard Levy put it this way: "Justices who look to the Constitution for more than a puzzling, if majestic, phrase might just as well turn to the comic strips for all the guidance they will find on how to decide most of the great cases that involve national public policy." Leonard W. Levy, Introduction to American Constitutional Law 1, 1 (Leonard W. Levy ed., 1960). See generally Paul Brest, The Misconceived Quest for the Original Understanding, 60 B.U. L. Rev. 204, 205 (1980) ("The text of the Constitution is authoritative, but many of its provisions are treated as inherently open-textured."); Richard H. Fallon, Jr., A Constructivist Coherence Theory of Constitutional Interpretation, 100 Harv. L. Rev. 1189, 1244 (1987) ("[W]hile arguments from text occupy the topmost rung of the thcoretical 
as necessary to fill the gaps in the text, including original intent (history), ${ }^{26}$ precedent, ${ }^{27}$ constitutional factfinding, ${ }^{28}$ constitutional scholarship, ${ }^{29}$ and contemporary values. ${ }^{30}$ These sources mark the boundaries of the Constitution and indicate the depth of implicated rights.

The legitimacy of government power depends also on the purpose behind its exercise. Constitutionally, government purposes are evaluated by the light of the defined right. The more deeply revered the right, the more light is cast upon the government's reasons for exercising its power. Applying the Constitution requires scrutiny ofwith varying degrees of rigor-the reasons justifying government action and the efficacy of that action to its stated purpose.

\section{The Application Prong: Assessing Government Interests}

Although the definition prong might appear to be the more engaging component of constitutional adjudication, it is only the first step in a two-step process. The apphication component is considered less interestimg under the conventional model, because this stage seems to

hierarchy, it seldom occurs that purely textual arguments unambiguously require a result contrary to that indicated by several other factors.").

Commentators are not unarimous on this point, however. Despite the general recoguition that " 'We are all realists now,'" John Monahan \& Laurens Walker, Social Science in Law: Cases and Materials 27 (2d ed. 1990), some courts and commentators continue to speak as though the meaning of the Constitution can be derived in ethereal abstractness, free of all earthly bounds. This oversight is troubling, for the social context exerts an imperious influence over constitutional adjudication. See David A.J. Richards, Pornography Commissions and the First Amendment: On Constitutional Values and Constitutional Facts, $39 \mathrm{Me}$. L. Rev. 275, 312-13 (1987) ("One of the most important, yet least examined, issues in public law is the way in which constitutional principles are or should be sensitive to related factual inquiries ...."). See generally Faigman, supra note 19, at 547 (examining the way in which constitutional principles are affected by related factual inquiries).

26 See, e.g., Henry P. Monaghan, Our Perfect Constitution, 56 N.Y.U. L. Rev. 353, 360 (1981) (stating that "original intent is the proper mode of ascertaining constitutional meaning").

27 See, e.g., Julius Stone, Precedent and Law: Dynamic of Common Law Gender 8 (1985) ("Constitutionality issues involve ... the meaning of preceding judicial decisions interpreting the texts."); see also Monaghan, supra note 26, at 360 ("[I]mportant concessions must now be made to the claims of stare decisis.").

${ }^{28}$ See, e.g., Faigman, supra note 19, at 548 ("Facts guide and restrain constitutional interpretation in the saine way as the other elements of constitutional theory.").

29 See Ely, supra note 10, at 56 (noting that many commentators have urged judges to engage in some form of "moral philosophy" when deciding constitutional questions).

30 See, e.g., Brest, supra note 25 , at 228 ("Precedents are nodified and even overruled to reflect perceived changes in social needs and values."). 
require merely overlaying the particular interpretation atop the government's action to assess the fit. This "mechanical jurisprudence" hardly can be expected to pique the constitutionally curious. ${ }^{31}$ In actuality, however, the apphication prong regularly provides the authority for particular results. If the Constitution is imphicated, the Court inust determine its full ineaning, and this done, review the purposes behind the government action in the hight of this imterpretation. The empirical connection between the governinent's purposes and the complained-of action thus becomes of constitutional concern. The Court must review the factual nexus between the action and the government's reasons for acting. This review requires the Court to face constitutional facts.

Professor Kenneth Culp Davis described two basic kinds of facts having evidentiary significance: legislative facts and adjudicative facts. ${ }^{32}$ Legislative facts are those facts that transcend the particular dispute and imform legal reasoning and the construction of legal rules. ${ }^{33}$ Adjudicative facts are those facts particular to the dispute. ${ }^{34}$ This dichotoiny roughly represents that kind of factfinding that takes place in constitutional adjudication. Davis' adjudicative fact category has a direct analogue in what imight be termed "constitutional-adjudicative" facts. His legislative fact category can be further refined into two subcategories, "constitutional-rule" facts and "constitutionalreview" facts. ${ }^{35}$ Constitutional-rule facts are rehed upon to substantiate a particular construction of the Constitution. They are used to establish the meaning of the Constitution and thus are relevant at the definition stage. Constitutional-review facts, on the other hand, becoine relevant at the application stage. Courts examine constitutional-review facts, which typically serve as the basis for the govern-

31 The "mechanical jurisprudence" of constitutional adjudication is not unlike that decried by legal realists in the early portion of this century. The realists focused the law's attention on the application of the law-on legal outcomes rather than legal logic. For a thorough history of legal rcalism, see John H. Schlegel, American Legal Rcalism and Empirical Social Science: From the Yale Experience, 28 Buff. L. Rev. 459 (1979).

32 Kenneth C. Davis, An Approach to Problems of Evidence in the Administrative Process, 55 Harv. L. Rev. 364, 402-03 (1942).

${ }^{33}$ See Fed. R. Evid. 201(a) Notes of Advisory Committee on 1972 Proposed Rules ("Legislative facts .... are those which have relevance to legal reasoning and the lawmaking process, whether in the formulation of a legal principle or ruling by a judge or court or in the enactment of a legislative body.").

34 See id.; Davis, supra note 32 , at 402.

35 For a general discussion of these subcategories, see Faigman, supra note 19, at 552-56. 
ment's action, under a chosen level of scrutimy in order to determine the constitutionality of the government's action.

Perhaps the most straightforward example of a constitutional-rule fact comes from Gibbons v. Ogden. ${ }^{36}$ Chief Justice John Marshall observed in Gibbons that "[a]11 America understands, and has umformly understood, the word 'commerce,' to comprehend navigation."37 Marshall's empirical behef regarding the general understanding of "all America" buttressed his reading of the Commerce Clause. Research demonstrating the incorrectness of this belief would liave weakened, though probably not changed, his conclusion. Throughout its history, the Court lias advanced empirical propositions to buttress its reading of the Constitution. ${ }^{38}$

More important for present purposes is the second form of constitutionally based legislative factfinding, constitutional-review facts. ${ }^{39}$ Constitutional-review facts encompass the vast number of cases in which the Court evaluates the factual basis supporting the government's reasons for acting. McGowan v. Maryland ${ }^{40}$ provides a straightforward example. Appellants complained that Maryland's Sunday Closmg Laws, whicli exempted sucli items as gasoline, fruit,

3622 U.S. (9 Wheat.) 1 (1824).

37 Id. at 190.

38 See, e.g., Ballew v. Georgia, 435 U.S. 223, 239 (1978) (setting the constitutional floor for jury size at six on the basis of empirical research on jury functioning with fewer than twelve members); Roe v. Wade, 410 U.S. 113, 163 (1973) (basing the parameters of the right of reproductive choice on medical teehnology); Brown v. Board of Education, 349 U.S. 294 (1954) (basing a constitutional right to integrated schooling on the empirical fact that separate schools were not equal); Lochner v. New York, 198 U.S. 45, 61 (1905) (assuming equality of bargaining power between employer and employee as support for constitutional protection of liberty of contract); Marbury v. Madison, 5 U.S. (1 Cranch) 137, 176-77 (1803) (implicitly assuming that legislators would be less faithful to a written Constitution than judges as support for judicial review). For a more expansive discussion of these and other cases see Faigman, supra note 19 , at $556-64$.

39 Constitutional-review facts are usefully contrasted with "constitutional-adjudicative facts." Once the Court determines the relevance of a constitutional rule, one of two types of constitutional fact presents itself. If the fact is particular to the dispute, it can be termed a constitutional-adjudicative fact. Juries are primarily responsible for resolving constitutionaladjudicative facts, although the standard of review of these findings has been the subject of some debate. Sec generally Henry P. Monaghan, Constitutional Fact Review, 85 Colum. L. Rev. 229, 230-34 (1985) (discussing "the scope of judicial review of the adjudicative facts decisive of constitutional claims"). By far the more prevalent kind of fact in constitutional adjudication is the constitutional-review fact.

40366 U.S. 420 (1961). 
newspapers, and drugs, violated the Equal Protection Clause. The Court observed:

It would seem that a legislature could reasonably find that the Sunday sale of the exempted commodities was necessary either for the health of the populace or for the enhancement of the recreational atmosphere of the day-that a family which takes a Sunday ride into the country will need gasoline for the automobile and may find pleasant a soft drink or fresh fruit; ... that newspapers and drug products should always be available to the public.

The record is barren of any indication that this apparently reasonable basis does not exist, that the statutory distinctions are invidious, that local tradition and custom might not rationally call for this legislative treatment. ${ }^{41}$

The Court examines constitutional-review facts with varying degrees of rigor. As indicated by the excerpt above, the McGowan Court reviewed the factual basis for the Maryland law under a rational basis standard. This standard involves the most cursory review of the reasons behind the government's action. Other laws might deinand greater scrutiny. If the law burdens fundainental rights or discriminates against "discrete and insular minorities," the Court reviews the government's reasons with great care. For instance, a state law barring the Sunday sale of only newspapers and magazines would invite the inost exacting scrutiny. The inagnitude of the review performed at the application stage thus seems to depend simply on the substantive interpretation fixed upon at the defimition stage. The main thesis of this Article, of course, is that these stages are not treated as separately as is commonly thought and thus the connection between definition and application is not as simple as it appears. Before endeavoring to prove my thesis, however, it is necessary first to consider the variety of strategies the Court uses to manage the intersection between definition and application.

\section{Definition Meets Application: Reconciling Individual Rights and Government Interests}

Although the Madisonian model illustrates the immanent clash of rights and interests in constitutional adjudication, the meeting of definition and application varies markedly in different constitutional con-

4 I Id. at 426. 
texts. The Court employs a wide range of methods to reconcile individual rights with competing government interests. ${ }^{42}$ This inethodological spectrum encompasses at one pole absolute-category definition, and at the other ad hoc balancing. This spectrum of constitutional methods represents, in theory, the varymg degrees to which the Court "balances" or accounts for competing government interests in the process of interpreting the Constitution. The absolutecategorical inethodologist seeks to discern finite categories in the Constitution. Asserted rights falling within a category receive absolute protection, but claimed rights that do not fit into a category receive no protection. In marked contrast, the ad hoc balancing methodologist atteinpts to identify those constitutional principles implicated by the case and weighs them against countervailing governmental interests on a case-by-case basis. Between these methodological extremes lie methods that incorporate category definition and balancing in varying degrees. Included on this spectruin would be nonabsolute category definition, definitional balancing, and multitiered balancing. The system's Madisonian premises, however, lurk within each method of constitutional adjudication irrespective of where it is located on this spectrum.

The categorical inode of adjudication is probably the quintessential method of constitutional interpretation. The primary object of the categorical method is to fix the scope of the Constitution's meaning from case to case through analogy and definition. ${ }^{43}$ For exainple, in Maryland v. Craig, ${ }^{44}$ the Court considered whether the Sixth Amendment's guaranty that a defendant have the right "to be confronted with the witnesses against him"45 was violated when the victim-witness (a six-year-old child) testified by means of a one-way closed circuit television. Justice Antonin Scalia, a strong proponent of the categorical method, ${ }^{46}$ argued in dissent that " 'to confront' plainly means to encounter face-to-face." 47 This inperative was obviously

42 See generally Craig R. Ducat, Modes of Constitutional Interpretation (1978) (discussing the "major schools" of constitutional interpretation which have grown out of Chief Justice Marshall's opinion in Marbury v. Madison).

${ }^{43}$ See T. Alexander Aleinikoff, Constitutional Law in the Age of Balancing, 96 Yale L.J. 943, 949-50 (1987).

44110 S. Ct. 3157 (1990).

45 U.S. Const. amend. VI.

46 See Antonin Scalia, The Rule of Law as a Law of Rules, 56 U. Chi. L. Rev. 1175 (1989).

47 Craig, 110 S. Ct. at 3173 (Scalia, J., dissenting). 
violated in Craig. Under Scalia's view, the government's reasons for removimg the witness from the courtroom were not pertinent to the constitutional inquiry. The Constitution set forth tlie "confrontation" principle and the present case ran afoul of that categorical requirement. The government's action, though presumptively valid, must be invalidated when opposed by a clearly announced constitutional riglit.

In this absolute form, categorical defimitions admit no exceptions and thus the government's reasons for actmg become irrelevant. The Constitution rarely permits such an absolutist approach, lowever, and the Court even more rarely invokes this method. ${ }^{48}$ Because the categorical metliod comes to admit exceptions, the Court finds itself increasingly in the busmess of balancing the constitutional right witl the government's reasons for infringing upon that right. On the spectrum of constitutional metliods, constitutional balancing assumes a variety of forms. ${ }^{49}$

Close to the categorical approach is "definitional balancmg," in which the Court assesses the weight of the right miplicated by a particular government action against the gravity of the government's interest in acting. ${ }^{50}$ Once this calculus is completed, the result is applied to future cases in the saine mexorable fashion as interpretations devised under the categorical method. Definitional balancing remains faithful to Madisoinan premises in theory, as the balancing metaphor itself symbolizes, by placing individual riglits on one scale and government purposes on another. New York v. Ferber ${ }^{51}$ illustrates definitional balancing in the context in which it first gained ascendancy, the First Amendment. ${ }^{52}$ In Ferber, the Court reviewed a New York criminal law that prohibited persons from "knowingly proinoting sexual performances by children under the age of 16 by dis-

\footnotetext{
48 See Chemerinsky, supra note 13, at 90 ("Because no constitutional rights are absolute, virtually every constitutional case involves the question whether the government's action is justified by a sufficient purpose.").

49 See, e.g., Laurent B. Frantz, The First Amendment in the Balance, 71 Yale L.J. 1424, 1434-35 (1962); Melville B. Nimmer, The Right to Speak from Times to Time: First Amendment Theory Applied to Libel and Misapplied to Privacy, 56 Calif. L. Rev. 935, 942-45 (1968).

so See generally Melville B. Nimmer, Nimmer on Freedom of Speech $\S 2.03$ (1984) (discussing definitional balancing).

51458 U.S. 747 (1982).

52 See Nimmer, supra note 49 , at 942.
} 
tributing material which depicts such performances."53 Although the law infrimged First Amendment speech, the Court sustained it on the basis of the "surpassing inportance" of the government interest in preventing the "sexual exploitation and abuse of children." 54 Justice Byron R. White, writing for the Court, found the value of child pornography to be, at best, minimal. When balancing this right against the overwhelming government interest in protecting the welfare of children, he concluded, "no process of case-by-case adjudication is required." $" 55$

Multitiered tests are a special form of definitional balancing, which perhaps best exemphify the shifting burdens of persuasion inherently a part of constitutional adjudication. For exainple, the Court has interpreted the Equal Protection Clause of the Fourteenth Amendment to mandate a three-tiered analysis that directs its review of government purposes and describes the corresponding burdens of persuasion. ${ }^{56}$ For rights at the core of the clause, the Court strictly scrutinizes the state action and requires the state to demonstrate that its action is necessary to accoinphish a compelling government interest. ${ }^{57}$ At the clause's periphery, the Court employs minimal scrutiny and requires the challenger to demonstrate that the state action is not rationally related to a legitimate state interest. ${ }^{58}$ Certain rights situated between the core and the periphery receive intermediate scrutiny, a standard that retains but reduces the burden on the state, requirmg it to demonstrate that its action is substantially related to an inıportant government interest. $^{59}$ The level of scrutimy, then, ostensibly depends

53458 U.S. at 749.

54 Id. at 757.

55 Id. at 764.

56 See John E. Nowak, Ronald D. Rotunda \& J. Nelson Young, Constitutional Law 530-31 (3d ed. 1986). See generally Monahan \& Walker, supra note 15 , at $582-89$ (using equal protection analysis to describe the allocation of the burden of persuasion in constitutional adjudication).

57 See, e.g., Palmore v. Sidoti, 466 U.S. 429, $432-33$ (1984).

58 See, e.g., Williamson v. Lee Optical Co., 348 U.S. 483, 488 (1955) (Under the minimal scrutiny applied by the Court, "[i]t [was] enough that there [was] an evil at hand for correction, and that it might be thought that the particular legislative measure was a rational way to correct it."); Hodel v. Indiana, 452 U.S. 314, 331-32 (1981) (Under the rational basis test legislation can be invalidated only "by a clear showing of arbitrariness and irrationality.").

59 See, e.g., Mississippi Univ. for Women v. Hogan, 458 U.S. 718, 724 (1982) (applying intermediate scrutiny to gender-based classifications); Caban v. Mohammed, 441 U.S. 380, 388 (1979) (applying intermediate scrutiny to a classification based on illegitimacy). 
on the Court's construction of the Constitution. Once the standard of review is established according to the individual interest affected, the Court applies this standard when reviewing the government interests. For the time being, this area of the law remains quasicategorical in that cases are fitted into one of the preexisting tiers of analysis. ${ }^{60}$

Standing at the opposite pole from the categorical approach, along the spectrum of constitutional inethods, is "ad hoc balancing."61 In its most extreme form, ad hoc balancing involves a gestaltian assessment and reconciliation of all of the rights and interests presented in the particular case. Justice Sandra Day O'Connor, writing for the Court in Maryland v. Craig, ${ }^{62}$ approached this extreme form of balancing in ruling on the constitutionahity of permitting a child molestation victim to testify against the defendant via closed-circuit television. Under her view, the Sixth Amendment's " 'preference for face-to-face confrontation' . . . 'must occasionally give way to considerations of public policy and the necessities of the case." "63 O'Connor assessed the depth of the defendant's right to face his accuser and concluded that it did not invariably outweigh the state's significant interests in child abuse cases. She explained that the Constitution requires district courts to determine on a case-by-case basis whether the psychological needs of the individual child outweigh the right of the defendant to confront his accuser. ${ }^{64}$

As the metaphor of a spectrum of methods suggests, the particular strategy the Court apphies in a given case imight fall between the methods described above or constitute a hybrid of one or more of these methods. Consistent across this spectrum, however, is the Madis-

60 Many Justices and commentators have observed that the multitiered methodology, which began with two tiers and now has three, is moving inexorably toward a more "sliding-scale" form of balancing. See San Antonio Indep. School Dist. v. Rodriguez, 411 U.S. 1, 98-99 (1973) (Marshall, J., dissenting); Jeffrey M. Shaman, Cracks in the Structure: The Coming Breakdown of the Levels of Scrutimy, 45 Ohio St. L.J. 161, 163 (1984). See generally Aleinikoff, supra note 43, at 968 (comparing the increasing inove to ease-by-case "sliding scale" balancing in the First Amendinent context to developments under the Fourteenth Amendment).

61 Nimmer, supra note 50 , at $\S 2.02$.

62110 S. Ct. 3157 (1990).

63 Id. at 3165 (quoting Ohio v. Roberts, 448 U.S. 56, 63 (1980) and quoting Mattox v. United States, 156 U.S. 237, 243 (1895), respectively).

64 Id. at 3169. O'Connor used the defimitional balancing method in Craig to derive an ad hoc balancing rule. Use of the definitional balancing inethod to derive an ad hoc balancing rule is not unusual. See, e.g., Lassiter v. Department of Social Serv., 452 U.S. 18, 26 (1981). 
onian preinise that in principle, interpretation should be separated from application.

Contrary to the requirements of these conventional premises, however, the Court often threads the state's reasons for acting into its construction of the Constitution. The herinetic seal encircling the definition prong has been broken, and the Court's failure to recognize the breach has resulted in broad areas of constitutional incoherence. By incorporating inajoritarian purposes into defining rights, the Court regularly misallocates the burdens of persuasion. The principal issue in governinent interests analysis concerns the factual nexus between the asserted state interest and the challenged state action. Hence, as the application prong increasingly intrudes into the definition prong, these einpirical questions are evaluated as a part of constitutional construction and the burden for deinonstrating thein rests upon the challenger of government action.

\section{Turning Madison on His Head}

Although the philosophical premises of the Constitution recominend a rigid separation of definition from application, the daily practice of constitutional adjudication belies this principle. ${ }^{65}$ Close analysis of the Court's opinions reveals low significantly government purposes influence the threshold interpretive inquiry, thus undermining any rational allocation of burdens of proving pertinent einpirical matters. This Section examines how the background noise of government interests lias confused the Court's jurisprudence. ${ }^{66}$

65 For the present, $I$ assume that the Madisonian model provides the best blueprint for constitutional adjudication and thus that, in practice, the art of construing the Constitution can be separated from the science of applying it. This assumption, however, is by no means a necessary or accurate one. I accept it here because the Court accepts it. The Court describes its work in accordancc with Madisonian principles. It attempts to divine rights that, only once ascertained, are assessed against the government's interest in infringing them. This is significant because it means that the Court speaks of the presumptive validity of state action and the need to allocate burdens of persuasion on the basis of its reading of the Constitution.

66 This Section is organized around the spectrum of constitutional methods identified in Section I as marking the meeting ground of definition and application. This organization was selected more out of convenience than principle. The reader need not fully accept my placement of cases to agree with my ccntral thesis. 


\section{A. An Introductory Exemplar: Defining the "Free Exercise of Religion"}

As noted above, of the sundry constitutional methods, the categorical mode probably appears to incorporate Madisonian principles the most scrupulously by rigidly separating definitional matters from apphication concerns and thus retaining the bulwark character of the Bill of Rights. The Constitution demarcates areas of mdividual hiberty that-at least in the abstract-are beyond the reach of majoritarian meddhing. For this reason, I use the Court's recent decision in Employment Division, Department of Human Resources $v$. Smith, ${ }^{67}$ a particularly good illustration of the categorical method, to provide an introductory overview of the Court's violation of the Madisonian structure. Moreover, the dissentimg and concurring opinions in Smith neatly encapsulate two other ways in which the Court reconciles individual rights with government purposes. The Smith decision, therefore, both illustrates how the Court mixes together the two prongs of conventional analysis and, by its concurring and dissenting opinions, serves as a springboard for an examination of the texture of this inixture along the constitutional spectrun.

In Smith, the Court considered whether Oregon could constitutionally deny uneniployment benefits to an American Indian dismissed from his job for the "religiously inspired" use of peyote. ${ }^{68}$ Justice Scalia framed the issue in Smith as involving the scope of the Free Exercise Clause. A review of the Court's cases, he observed, imdicated that the denial of benefits under the present circumstances did not implicate free exercise rights that would trigger application of a compelling interests test. ${ }^{69}$ Indeed, Scalia rejected the use of the conipelling interest test in free exercise cases as an "anomaly."70 Although Scaha's conclusion is based on a multitude of factors, principal among these is the coinbination of the governnient's need to regulate con-

67494 U.S. 872 (1990).

68 Id. at 876.

69 A precursor of Smith is Bowen v. Roy, 476 U.S. 693 (1986), in which the Court refused to extend the compelling interest test of the Free Exercise Clause to "a religiously based objection to the statutory requirements that a Social Security number be provided by an applicant seeking to receive certain welfare benefits." Id. at 695 . Chief Justice Warren E. Burger, writing for the Court, held that when a "facially neutral and uniformly applicable requirement" burdens religious conduct, the government must show only that the requirement "is a reasonable means of promoting a legitimate public interest." Id. at 707-08.

70 Smith, 494 U.S. at 886. 
trolled substances ${ }^{71}$ and concern over the effects of subjecting all similar government regulations to the rigors of the compelling interest standard. ${ }^{72}$ Scaha thus defined the Free Exercise Clause to exclude "religiously imspired" peyote use largely on the basis of the state's pressing need to regulate drug use in a uniform inanner. ${ }^{73}$

Justice O'Connor, who concurred in the Court's judgment, wrote separately to express her inability to square Scalia's reading of the Free Exercise Clause with case law and common understanding. She observed, "It is difficult to deny that a law that prohibits rehioiously inotivated conduct, even if the law is generally applicable, does not at least implicate First Amendment concerus."74 Thus implicated, the Free Exercise Clause requires the Court to scrntinize the basis for the government action. ${ }^{75}$ This scrutiny involves a particularized review of the facts, with the government bearing the burden of persuasion: "Even if, as an empirical matter, a government's criminal laws night usually serve a compelling interest in health, safety, or public order,

71 See id. at 885 ("The government's ability to enforce generally applicable prohibitions of socially harmful conduct, like its ability to carry out other aspects of public policy, 'cannot depend on measuring the effects of a governmental action on a religious objector's spiritual development." ") (quoting Lyng v. Northwest Indian Cemetery Protective Ass'n, 485 U.S. 439, 451 (1988)).

Similarly, in Bowen, a principal justification for applying minimal scrutiny was the government's interests in administering its welfare system. Justice O'Connor dissented, arguing that the compelling interest standard applied and that the government had not produced any evidence to meet it. 476 U.S. at 730 . It is useful to coinpare O'Connor's opinion in Bowen, in which she found that the state failed to carry its burden, with her opinion in Smith, in which she believed that the state met its burden. See infra notes 74-77 and accompanying text. See also Michael W. McConnell, Free Exercise Revisionism and the Smith Decision, 57 U. Chi. L. Rev. 1109, 1126-27 (1990) (comparing Bowen and Smith).

72 See Smith, 494 U.S. at 888.

If the "compelling interest" test is to be applied at all, then, it must be applied across the board, to all actions thought to be religiously commanded. Moreover, if "compelling interest" really mcans what it says (and watering it down here would subvert its rigor in the other fields where it is applied), many laws will not meet the test.

Id.

73 The following passage captures Scalia's majoritarian perspective:

It may fairly be said that leaving accommodation to the political process will place at a relative disadvantage those religious practices that are not widely engaged in; but that unavoidable consequence of democratic government must be preferred to a system in which each conscience is a law unto itself or in which judges weigh the social importance of all laws against the centrality of all religious beliefs.

Id. at 890 .

74 Id. at 893-94 (O'Connor, J., concurring).

75 Id. at 901-02 (O'Connor, J., concurring). 
the First Amendment at least requires a case-by-case determination of the question, sensitive to the facts of each particular claim."76 After reviewing the present facts under the compelling interest standard, O'Connor concluded that the denial of benefits did not offend the Free Exercise Clause. ${ }^{77}$

In reaching this conclusion, O'Connor accepted on its face the government's argunient that grave harm would result if the petitioners were exenipted from the state's general prohibition on peyote use. The government thus met its burden of persuasion under the strictest level of scrutiny simply by announcing the reason for its actions.

The dissenters, on the other hand, apphed a more exacting level of scrutiny. Justice Harry A. Blackmun, joined by Justice William J. Brennan and Justice Thurgood Marshall, argued that the Constitution's conipelling interest test requires the governnient to prove the necessity of its action: "[T]his Court's prior decisions have not allowed a governnent to rely on mere speculation about potential harms, but have deinanded evidentiary support for a refusal to allow a religious exception." 78 When the conipelling interest standard can be met on the basis of "mere speculation," the judicial scrutiny applied is strict in name alone. Blackmun's denıand for "proof" of the social harm supposedly addressed by the government's action forms a greater barrier to overcome. ${ }^{79}$

In the end, O'Connor shared Scalia's conclusion that under the facts of Smith no constitutional violation had occurred. Yet she reached this conclusion in a very different way. Scalia evaluated the basis for the state action in the process of defining the scope of the Free Exercise Clause; O'Connor defined the Free Exercise Clause first and then weighed this defined right against the reasons for the state action. Their convergence in outcome is intelligible if the governnent interests were sufficiently compelling and demonstrable-if in meeting O'Connor's strict scrutiny they naturally satisfied Scalia's cursory

76 Id. at 899 (O'Connor, J., concurring).

77 Id. at 905-07 (O'Connor, J., concurring).

78 Id. at 911 (Blackmun, J., dissenting).

79 The difficult and complex issue raised by Blackmun's dissent is whether under heightened scrutiny the state must produce "proof" of the existence of facts supporting its action or whether reasoned argument will suffice. Indeed, the question of the nature of the burden of proof that different standards of review place upon the government naturally follows from the arguments made here. I must defer consideration of this important issue to another article. 
review. Alternatively, and more likely, this convergence is a function of O'Connor's deferential strict scrntiny review. Scalia and O'Connor reviewed the government's reasons with similar exactitude, but with Scalia working in the definition prong and O'Connor working in the application prong. Although the effects of these two interpretive strategies look the same, the choice of prong itself has great constitutional significance.

The point at which the government interests are evaluated is much more than a procedural incety. At the defintion stage the Madisonian paradigm deniands a very different standard of review than is required at the application stage. Government interests rehed upon when defining the constitutional text are not reviewed substantively. In Smith, the pertinent issue at the definition stage concerned the parameters of free exercise, and Scalia merely identified the government's interests in the matter. Indeed, under Scalia's approach, at the threshold of constitutional adjudication, the challenger effectively bears the burden of proving that there is no rational nexus between the regulation and a legitnnate government interest, because she is invoking the Constitution to defeat the majority will. By incorporating governmental purposes into the definition prong, rather than reviewing these interests when applying the principles derived through interpretation, the Court shifts the burden of denionstrating the empirical propositions that refute or support the government's action froin the state to the challenger. ${ }^{80}$

O'Counor and Blackmun, on the other hand, both employed a multitiered balancing inethod that kept the einpirical burden on the government, although they disagreed on how to read the result. Because O'Counor did not require the state to introduce research deinonstrating that its action was necessary to accoinphish a coinpelling state mterest, the real burden on the state was shight. Yet, disagreennents with O'Counor are easier to perceive, because she articulated the conflict between individual rights and government interests in a tradi-

${ }^{80}$ See generally Richard K. Sherwin, Rhetorical Pluralism and the Discourse Ideal: Countering Division of Employment v. Smith, A Parable of Pagans, Politics, and Majoritarian Rule, 85 Nw. U.L. Rev. 388, 423 (1991) ("[T]he majority in Smith not only abandons principled discourse, but explicitly defers to the political process and its dominant discourse of pluralist bargaining among competing interests. The institutional role of judicial review thus blends into legislative policy management. As a result, the judiciary's check upon the legislature is lost."). 
tional manner. Readers can disagree with O'Connor over whether the state met a sufficient burden in light of the rights at stake. ${ }^{81}$ In contrast, Scalia's categorical metliod evaded any empirical analysis by removing it to the definition prong. There, government interests do not conipete with imdividual rights but merely assist im the construction of those rights. The balancing formula advanced by O'Connor and Blackmun, then, adlieres to Madisonian principles with greater fidelity in tliat it separates riglits and niterests onto different scales for weigling. ${ }^{82}$

Altlough Justice O'Connor's concurrence in Smith generally conformed to the Madisonian paradigm, the facility with whicl slie found that the government niet the compellimg imterest standard miglit leave the reader im sonie despair. At the least, O'Connor's concurrence raises a couple of questions for the present thesis. First of all, does it really nıatter for constitutional theory whetlier the Court analyzes government interests in the application prong or im the definition prong if, as evidenced in $\mathbf{S m i t h}$, their placen1ent does not necessarily affect the result? There are several possible responses to this query. Initially, simply as a matter of imtellectual integrity, judges slould say wliat they are doing. Defining a riglit differs markedly from evaluating the government's justification for infrimging a right. Justice O'Connor's opinion, thouglı having little persuasive potency, at least conforms to the basic operating premises of the Constitution. Moreover, not all opimions whicl merge definition and application do so as clearly as Scalia's im Smith. By beclouding its operating premises, the Court is able to skirt significant scloolarly criticisnı. Clarifying the stages of constitutional analysis sliould lead to clearer and niore consistent opimons. Justice O'Coimor, for nistance, sliould be expected to clarify what, if any, enipirical research sliould be produced by the government to meet the compelling interest standard; ${ }^{83}$

81 See McConnell, supra note 71, at 1113 (noting that the result of the compelling interest test in Smith is "a close question").

82 Balancing formulas do not guarantee adherence to such principles. See infra Section II.B. for examples of the Court's failure to separate interpretation matters from application matters in different balancing contexts.

83 Justice O'Connor has been quite inconsistent on the issue of the quantum of proof necessary to meet the compelling interest standard. As noted supra note 71, she explicitly called for empirical research under this standard in Bowen v. Roy. And just this last term she joined Justice John Paul Stevens' dissent in Burson v. Freeman, 112 S. Ct. 1846 (1992), criticizing the plurality for "blithely dispens[ing] with the need for factual findings" under the 
and Justice Scalia should have to defend his methodological sloppiness. To be sure, the ultimate value choices or conclusions of constitutional adjudication can usually be defended, even if only weakly; it is the structure of constitutional argument that is most susceptible to critical review and critical check. Just because constitutional theory indicates that a particular course should be followed does not mean that the Court will follow it. The force of constitutional commentary resides in its ability to lay bare erroneous assumptions and inconsistent logic in order to expose the weaknesses of the argument. It can only be hoped that future courts will follow a truer course.

Still, another question persists: What advantage does the Court gain by importing government interests into the definition prong in this way? The answer is that this strategy permits the Court to avoid a host of difficulties that would einerge if it followed Madisoman principles too rehiously. At bottoin, government interests analysis rests on the factual foundation supporting the government's reasons for acting. Constitutional factfinding, however, has not been an area of distinction for the Court. ${ }^{84}$ In a great many cases, the constitutional facts of relevance involve complex psychological or sociological inatters that inake sound empirical investigation difficult or impossible. ${ }^{85}$ These constitutional facts create probleins in two particular ways.

First, because these constitutional facts, which are so necessary to constitutional lawinaking, are often uncertain or unavailable, a risk exists that, as interpreted, the bedrock of the Constitution will rest on shaky ground. This quandary has troubled the Court, because under-

strict scrutiny standard. Id. at 1863 (Stevens, J., dissenting). In Burson, the Court upheld Tennessee's prohibition on campaign activity within 100 feet of an entrance to a polling place. Justice Stevens' criticism in Burson could easily be direeted at O'Connor's opinion in Smith: [A]lthough the plurality recognizes the probleinatic character of Tennessee's contentbased suppressive regulation it nonetheless upholds the statute because "there is sinply no evidence" that commercial or charitable solicitation outside the polling place poses the same potential dangers as campaigning outside the polling place. This analysis contradicts a core premise of strict scrutiny-namely, that the heavy burden of justification is on the State. The plurality has effectively shifted the burden of proving the necessity of content discrimination from the State to the plaintiff.

Id. at 1866 (Stevens, J., dissenting) (citations omitted).

84 See Faigman, supra note 19, at 564 ("Constitutional facts [are] only roughly based on einpirical rcality; they exist[ ] in a nether world, somewhere within the Constitution itself."); Richards, supra note 25 , at 313-17 (using the Court's equal protection decisions to illustrate both the importance that constitutional facts assume in constitutional interpretation and the difficulty inherent in passing judgment on those underlying einpirical facts).

85 See Faigman, supra note 19, at 606. 
standably it does not want its pronouncements to depend on incomplete and changeable factual information. ${ }^{86}$ The Madisonian framework, with its shifting burdens of persuasion, avoids this problem, at least in theory. By imposing the burden of persuasion on one of the parties, the framework seeiningly puts the problem of ambiguous or unavailable information beyond the Court's reach. The party bearing the burden of persuasion simply loses under conditions of ambiguity. Because the Constitution estabhished who would bear this burden, the law progressed apparently free of the ambiguities of factfinding. The distribution of burdens which the framework establishes, however, gives rise to the second type of problem.

Traditional constitutional analysis allocates the burden of deinonstrating pertinent constitutional facts to the state when deeply perceived rights are inplicated. When the prospect of obtaining valid einpirical research appears reinote, the Court hesitates before giving the state a burden that it can never meet. The Court has two alternatives in such cases if it is not going to find that the government always loses when the factual basis for its action cannot be einpirically demonstrated. The Court could relax its close scrntiny of deeply revered rights and not require any social or einpirical research from the state. O'Connor's opinion in Smith is an example of this strategy. She conducted a perfunctory review of the asserted basis for the governinent action and found it compelling. The obvious problem with this strategy is that the precedent of not requiring proof weakens close scrutiny of state action in other cases. Moreover, it is subject to intense criticisin from other Justices and commentators who lament the state of judicial protection of individual rights.

The second option is to transpose the factual preimises of government interests analysis mto rights definition as Scalia did in Smith.

86 In Lockhart v. McCree, 476 U.S. 162 (1986), for example, Justice William H. Rehnquist (now Chief Justice) vehemently criticized the empirical research introduced to support the petitioner's contention that removing jurors who oppose capital pumshment would result in a jury biased in favor of conviction. Nonetheless, Rehnquist went on to find that even if research reliably demonstrated such conviction-prone juries, these facts would not constitute a constitutional violation. Rehnquist thus crafted his decision so that it would not rest on vulnerable ground. Sec Samuel R. Gross, Overruled: Jury Neutrality in Capital Cases, Stanford Law., Fall 1986 at 11, 13 (noting that a decision based solely on the insufficiency of the evidence tending to prove that prodeath penalty juries are unfairly conviction-prone "would have been an invitation for future litigation based on additional studies and even fuller records"). 
This removes the burden of producing social authority entirely froin the state. The elegance-and deceptiveness-of this strategy lies in its capacity to make constitutional decisions that actually rest on uncertain factual moorings appear to rest on the sohd bedrock of deference to majoritarian decisionmaking. By selectively incorporating government interests into rights definition, the Court can avoid the weaknesses associated with constitutional factfinding.

Close study of the Court's cases demonstrates that it increasingly avoids placing too great a burden on the state by using the government's reasons for infringing an individual right to define that right. This practice means that the state need not meet a heavy burden to justify infringements of fundamental hiberties, because the Court uses the government's justifications to redefine the hiberties as nonfundamental, if not nonexistent. Of course, the factual questions remain an integral part of the constitutional scheme, but now the challenger of state action suffers the ambiguity of empirical research. This technique also permits the Court to avoid explicitly relying upon constitutional facts. Hence, the Court can proceed with constitutional interpretation as though it were not dependent on unrehable facts when, in reality, its very core is infested with factual ambiguity. The next Section examines this practice across the full spectrum of constitutional methodologies.

\section{B. Reconciling Individual Rights and Government Interests Along the Spectrum of Constitutional Methods}

The Court uses widely varying inethods to reconcile majoritarian power with individual hiberty in different constitutional contexts. The Madisonian structure, however, informs the Court's method throughout all contexts. Although different constitutional provisions have varied histories, they all share the fundamental principle of accommodation between the inajority and the individual. But the Court, in attempting to traverse this path, increasingly appears to have lost its bearings. This Section traces the erratic course the Court has pursued and examines how the Madisonian ideal has become despoiled across the spectrum of constitutional inethods.

\section{Category Definition}

The threshold question in all constitutional adjudication asks whether the Constitution is inplicated. Thus, all constitutional meth- 
ods contain soine categorical attributes. Irrespective of the method the Court eventually adopts to resolve particular conflicts of individual rights and government interests, it must first determine the constitutional category into which the rights fall. The Court has no authority to review the inherent vahidity of state action on other than constitutional grounds. If the Constitution is implicated, lowever, the full spectruin of constitutional methods becoines available. When the categorical metliod is adopted, the threshold inquiry and the broader question become one: constitutional inplication signifies constitutional protection. Scalia's opinion in Smith, considered in the previous Section, illustrates this circumstance. Under a pure version of this approach, government interests should never come into play at all. Obviously, this is rarely, if ever, the case.

\section{a. Defining "Liberty" and "Property"}

The Fourteentlı Amendment prohibits any state from depriving a person of "life, liberty, or property, without due process of law."87 This provision requires the Court imitially to define the terms "life," "liberty," and "property" before determiming wliat "process" is "due." The categorization process assuines great importance, because the Court reviews only those deprivations having constitutional stature.

In Paul v. Davis, ${ }^{89}$ respondent brouglit an action under 42 U.S.C. $\S 1983$ claiming that lie was defamed by a flyer distributed by the local police department that identified him as an "active slioplifter." "90 The respondent had been arrested but never tried for shopliftimg. He claimed that the pohce's action mjured his reputation and thus deprived him of some "liberty" protected by the Fourteenth Amendment. ${ }^{91}$ Under $\S 1983$, respondent "liad to sliow that [the police] had deprived hiin of a riglit secured by the Constitution."92

\footnotetext{
87 U.S. Const. amend. XIV, § 1.

88 See Board of Regents v. Roth, 408 U.S. 564, $570-71$ (1972) ("[The Court must] determine whether due process requirements apply in the first place . ...").

89424 U.S. 693 (1976).

90 Id. at 697.

91 Id.

92 Id. at 696-97. Section 1983 also requires that the deprivation be under color of law. This element of $\S 1983$ was not in dispute. Id. at 697 n.2.
} 
The initial query thus concerned whether the concept of "hiberty" encompasses reputation. The Court concluded that it did not.

Chief Justice William H. Rehnquist, writing for the Court, asked whether the Due Process Clause "should ex proprio vigore extend ... a right to be free of injury wherever the State may be characterized as the tortfeasor."93 If so, Rehnquist observed, it "would make of the Fourteenth Amendment a font of tort law to be superimposed . . . by the States."94 This constrnction would produce untenable consequences: "Respondent's construction would seem almost necessarily to result in every legally cognizable [state inflicted] injury . . . estabhishing a violation of the Fourteenth Amendment."95 Rehnquist's analysis confuses the construction of "hiberty" with the potential consequences following from that construction. ${ }^{96}$ Finding the Due Process Clause to be iniphicated does not mean it is necessarily violated. The ultiniate constitutional query is not whether liberty has been deprived, but whether it has been deprived without due process. ${ }^{97}$

Defining "liberty" in Paul effectively became an exercise in limiting the consequences flowing from any particular definition employed. Rather than balance the consequences of extending the liberty right agamst the magnitude of that right, the Court narrowed the definition of hiberty on account of these consequences. Professor Heury P. Monaghan explained the point well: "[T]

93 Id. at 701.

94 Id.

95 Id. at 699. See also Henry P. Monaghan, Of "Liberty" and "Property," 62 Cornell L. Rev. 405, 427 (1977) (commenting that Rehnquist's argument "seeins to assume that the tortious character of the state official's conduct, if proved, would of necessity establish a constitutional violation").

96 Justice Brennan, writing in dissent noted the confusion:

[The Court] simply fails to recognize the crucial difference between the question whether there is a personal interest in one's good name and reputation that is constitutionally cognizable as a "liberty" or "property" interest . . . and the totally separate question whether particular government action with respect to that interest satisfies the inandates of due process.

Paul, 424 U.S. at 727-28 (Brennan, J., dissenting).

97 Chief Justice Rehnquist has exhibited his understanding of this distinction in other contexts. In Parratt v. Taylor, 451 U.S. 527 (1981), overruled by Daniels v. Williams, 474 U.S. 327 (1986), a prisoner brought a $\S 1983$ action for the negligent deprivation of a hobby set worth $\$ 23.50$. Id. at 529 . Rehnquist conceded that the hobby set was property and had been deprived but explained that these issues were only the start of the constitutional question: "Nothing in [the Fourteenth] Amendinent protects against all deprivations of life, liberty, or property by the State. [The Amendment] protects only against deprivations 'without due process of law.' " Id. at 537 (quoting Baker v. McCollan, 443 U.S. 137, 145 (1979)). 
cases out of the federal courts was great, and so a compromise was struck. Rather than facing the balancing question at the merits stage, the Court struck a coinpromise at the definitional stage."98 The Court did not entirely fail to consider the empirical consequences of an expanded liberty right, therefore, it simply moved this application query to the definition prong.

In addition to transplanting into the definition prong the "dire" consequences of making the Fourteenth Amendment "a font of tort law," Relinquist mvoked state law to give content to the hiberty category: "[I]nterests attain this constitutional status by virtue of the fact that they have been mitially recognized and protected by state law .99 Similarly, and indeed more prominently, the Court lias explicitly given state law constitutional dimensions in the context of defining "property." Justice John Paul Stevens expressed this position unambiguously in Bishop v. Wood:100 "[T] claim of entitlement must be decided by reference to state law. . . . Whether such a guarantee has been given can be determined only by an examination of the particular statute or ordinance in question."101

The Court's argument that the constitutional categories of "liberty" and "property" should be coterminous with state law definitions rests on governmental and mstitutional concerns, ratlier than traditional constitutional autliorities. In Paul, Rehnquist largely ignored the historical content of the "liberty" coinponent of due process. ${ }^{102}$ In its property cases, the Court fails to explain the constitutional principle that limits due process to state-defined property in a satisfactory way. Without question, property rights typically flow from "existing rules or understandings that stem from an imdependent source such as state law," ${ }^{103}$ but this argument overstates the point. As other commentators liave observed, certain imterests deserve constitutional pro-

\footnotetext{
98 Monaghan, supra note 95 , at 429.

99 Paul, 424 U.S. at 710. For a different rationale for Paul than the one Rehnquist offers, see Rodney A. Smolla, The Displacement of Federal Due Process Claims by State Tort Remedies, 1982 U. Ill. L. Rev. 831, 846-47 ("The result [in Paul] . . was not justified by the reason Justice Rehnquist gave - that Kentucky law did not extend its protection to Mr. Davis' reputation-but by precisely the opposite fact: because Kentucky law did protect Davis, Kentucky did nothing to violate the due process clause." (emphasis omitted)).

100426 U.S. 341 (1976).

101 Id. at 344-45 (footnote omitted).

102 See Monaghan, supra note 95 , at 427.

${ }_{103}$ Bishop, 426 U.S. at 344 n.7.
} 
tection as property regardless of the state's definition. ${ }^{104}$ The Court's reliance on the state's discretion eviscerates the essential Madisonian principle that the majority should not define the limits of its own powers. The Due Process Clause restrains majority tyranny of liberty and property, then, only at the sufferance of the majority. Thus constituted, the clause stands as a frail bulwark against tyrannical winds.

\section{b. Defining "Cruel and Unusual Punishment"}

The Eighth Amendment forbids state imposition of cruel and unusual punishments. Yet, the Court has never found the death penalty itself to be cruel and unusual. ${ }^{105}$ Instead, the Court scrutinizes state death penalty schemes to ensure that an otherwise constitutional penalty is not imposed in an unconstitutional maimer. Because the death penalty does not fall within the purview of the Eighth Amendment, however, this scrutiny is deferential to the legislative will. ${ }^{106}$ Put differently, the petitioner bears the burden of demonstrating the arbitrariness or capriciousness of a particular capital sentencmg scheme in order to prove that the Constitution is implicated.

The Eighth Amendment inquiry represents the mirror image of due process described in the previous Section. In the liberty/property context, the challenger's inability to get into the category means the Court will not substantively review the strength of the government's interests; the government's action will be sustained. In the Eighth Amendment context, if the punishment is found to be cruel and unusual no state justification would save it; the government's action will be invalidated. In both the due process and the Eighth Amendment contexts, therefore, the Court uses government interests at the definition stage to narrow the scope of the respective right. In due process cases, this strategy operates to keep the challenger out of court and in Eighth Amendment cases it operates to keep the government in court.

The definition prong of Eighth Amendment analysis presents the Court with special difficulty. The ainendment's direction that "cruel and unusual pumshments" are forbidden provides little illumination regarding the specific punishinents that do not pass constitutional

t04 See, e.g., Monaghan, supra note 95, at 435 (drawing a distinction between interests, which are generally dependent upon state law, and the characterization of those interests as "property").

105 Gregg v. Georgia, 428 U.S. 153, 169 (1976).

106 Id. at 175. 
muster. History, im the form of original intent, has been especially unhelpful in clarifying acceptable modes of punishment. Many punishments regularly practiced at the time of the framing of the Eighth Ainendment are not tolerated today. ${ }^{107}$ More than any other amendment, perhaps, construction of the Eighth Amendment has depended on modern sensibilities and, not surprisingly, the government's reasons for imposing the death penalty.

The constitutionality of capital punishment rests on two arguments, retribution and deterrence. ${ }^{108}$ Both of these bases represent the government purposes underlying capital pumshınent statutes. They are advanced by the Court, however, not to justify capital punishment under the Eighth Amendment, but instead to fix the meaning of "cruel and unusual." 109

Retribution is often assumed to be sufficient to sustain capital punishment on its face. But the Court has buttressed its normative conclusion on the basis of two factual assuniptions. First, the Court has argued that the failure of the system to provide for "normal" impulses would lead to increased vigilantism. ${ }^{110}$ Secondly, the Court has rehed

107 See, e.g., In re Kemmler, 136 U.S. 436, 447 (1890) ("Punishments are cruel when they involve torture or a lingering death."); Wilkerson v. Utah, 99 U.S. 130, 136 (1878) ("[I]t is safe to affirm that punishments of torture ... are forbidden by that amendment."). See generally Trop v. Dulles, 356 U.S. 86, 101 (1958) (The Eighth Amendment "must draw its meaning from the evolving standards of decency that mark the progress of a maturing society."); Weems y. Umited States, 217 U.S. 349, 378 (1910) (The scope of cruel and unusual punishments "is not fastened to the obsolete but may acquire meaning as public opinion becomes enlightened by a humane justice.").

108 Gregg, 428 U.S. at 183-87; id. at 233 (Marshall, J., dissenting) ("The two purposes that sustain the death penalty as nonexcessive in the Court's view are general deterrence and retribution.").

109 Yet, the Eighth Amendment arguably differs from other constitutional contexts in that it appears to itself incorporate goverument interest analysis into the definition of the right. This conclusion has been rejected by other commentators, see, e.g., Chemerinsky, supra note 13, at $88 \mathrm{n} .200$, and would permit, if taken to its logical conclusion, evisceration of the right through sufficient majoritarian action. See infra note 114 and aceompanying text. It is not difficult to imagine defining "cruel and unusual" by resort to contemporary comnunity values without relying on governnent interests. For instance, scientific surveys of voters might be preferred over a survey of state statutes. See infra note 113. The substantive content of the Eighth Amendment is beyond the scope of this Article. To be sure, however, insofar as specific constitutional provisions themselves incorporate goverument interests in their definitions, the Court can legitimately rely on these factors at the definitional stage.

110 Concerned with the possibility that without capital punishment the public might turn to self-help, the Court observed:

The instinct for retribution is part of the nature of nian, and channeling that instinct in the adninistration of criminal justice serves an important purpose in pronoting the 
on contemporary values, finding support for the retributive impulse of the general public in state legislation overwhelmingly sanctioning the death penalty.

Virtually any degree of scrutiny of the einpirical foundation for the Court's retribution rationale would reveal the paucity of evidence for it. Foreinost, neither empirical research nor common sense supports the view that the public will form lynch inobs when convicted murderers receive life imprisonment instead of death. ${ }^{111}$ On the other hand, the public's support of the death penalty - as a measure of the retributive impulse-is a inore complex issue. The Court has consistently used state legislation as its measure of the public view. ${ }^{112}$ This measure is troubling on at least two accounts. First, it is, at best, ouly a rough approximation of the general pubhic's views. Opimion polls indicate a lack of consensus on the "cruelty" of the death penalty, especially in difficult cases in which most state legislation still authorizes it. ${ }^{113}$ Second, logic does not recommend the use of state statutes authorizing capital pumshment to ascertain the meaning of "cruel and

stability of a society governed by law. When people begin to believe that organized society is unwilling or unable to impose upon criminal offenders the punishment they 'deserve, then there are sown the seeds of anarchy - of self-help, vigilante justice, and lynch law.

Gregg, 428 U.S. at 183 (quoting Furman v. Georgia, 408 U.S. 238, 308 (1972) (Stewart, J., concurring)).

111 See Furman v. Georgia, 408 U.S. 238, 303 (1972) (Brennan, J., concurring) ("There is no evidence whatever that utilization of imprisonment rather than death encourages private blood feuds and other disorders.").

112 The Court has also sometimes referred to the decisions of sentencing juries as a measure of public sentiment. See, e.g., Thoinpson v. Oklahoina, 487 U.S. 815, 831 (1988) (plurality opimion); Enmund v. Florida, 458 U.S. 782, 794-96 (1982).

113 Although, according to a 1988 Gallup Poll, $79 \%$ of respondents supported the death penalty for persons convicted of inurder, George Gallup, Jr., The Gallup Poll: Public Opinion 1988 at 250 (1989), this percentage drops significantly when examined inore closely. In a 1986 Gallup Poll, for instance, $70 \%$ supported the death penalty for convicted murderers, but only $55 \%$ did so when offered the alternative of life imprisonment without parole. George $\mathrm{H}$. Gallup, Jr., The Death Penalty, Gallup Reports, Jan.-Feb. 1986, at 10-16. Additionally, polls consistently indicate lack of support for inposing the death penalty when the defendant is mentally retarded. See Advocates Want Mentally Retarded Protected From Death Penalty, Proprietary to the U.P.I., Feb. 2, 1989, Regional News (mentioning a University of Maryland study indicating that whereas $67 \%$ of respondents favored the death penalty for those convicted of murder, $82 \%$ did not support it for inentally retarded convicts); Groups Urge Abolition of Death Penalty, Proprietary to the U.P.I., Jan. 9, 1989, Regional News; Stephen Chapinan, Do We Have a Right to Execute a Child in a Man's Body?, Chi. Trib., Jan. 15, 
unusual" in order to test the constitutionality of those very same statutes. ${ }^{114}$

Deterrence, the alternative justification for the death penalty, and the justification more exphcitly empirically based, has been the subject of especially heated debate. The Court first visited the issue of the death penalty's deterrent effect in Furman $v$. Georgia, ${ }^{115}$ but like the researchers im the area, could reach no consensus. The Court revisited this intractable question in Gregg $v$. Georgia ${ }^{116}$ again reaching no consensus other than concluding that the issue did not fall within its job description: "The value of capital punishment as a deterrent of crime is a complex factual issue the resolution of which properly rests with the legislatures, which can evaluate the results of statistical studies in terms of their own local conditions and with a flexibility of approach that is not available to the courts."117

McCleskey v. Kemp ${ }^{118}$ represents a remarkable, and regrettable, example of deference to the legislative will even in the face of actual evidence of arbitrary and capricious imposition of capital punishment. Justice Lewis F. Powell, writing for the Court, accepted the validity of an empirical study conducted by David Baldus and others (the "Baldus study") that indicated that "defendants charged with killing white victims were 4.3 times as likely to receive a death sentence as defendants charged with killing blacks." 119 Rather than evaluating this evidence himself, however, Powell referred these troubling statis-

1989, at C36 (reporting a Louis Harris Poll indicating that $70 \%$ of those surveyed opposed the death penalty for the mentally retarded).

Interestingly, in Penry v. Lynaugh, 492 U.S. 302, 334-35 (1989), Justice O'Connor, writing for the Court, disinissed the value of opinion pqlls as being insufficiently objective to assist in resolving the constitutionality of imposing the death penalty on the mentally retarded. She relied instead on the "objective" data provided by state statutes, a majority of which permit the imposition of the death penalty for the mentally retarded. O'Connor never explained why state statutes are objective and opinion polls are not, on the issue of public attitudes regarding the death penalty.

114 See Ely, supra note 10, at 69 ("[1]t inakes no sense to employ the value judgments of the inajority as the vehicle for protecting minorities from the value judgments of the inajority.").

115408 U.S. 238 (1972).

116428 U.S. 153 (1976).

117 Id. at 186.

118481 U.S. 279 (1987).

119 Id. at 287. 
tics to the legislatures to contemplate. ${ }^{120}$ The government's reasons for imposing the death penalty kept the death penalty safe from constitutional objection except im narrowly defined circumstances. Those circumstances then proved to be effectively unmeetable, because in making that final determination the Court further deferred to the legislative judgment. Instead, the responsibility for examining statesponsored discrimination was left to the state.

Gregg's categorization of the death penalty as not "cruel and unusual" dictated the deferential posture the Court adopted toward the state's death penalty scheme in McCleskey. The dynamic between these two cases deserves to be highlighted. The original categorization in Gregg was informed by a government interests analysis that placed the burden on the challenger to refute the twim arguments of retribution and deterrence. Although this placement at first seems natural because the challenger traditionally bears the burden of persuasion at the definition stage, closer scrutmy reveals its violation of Madisoman premises. Moreover, this violation led to the deferential review of the scheme im $\mathbf{M c C l e s k e y . ~ C o n s e q u e n t l y , ~ i m ~ E i g h t h ~ A m e n d - ~}$ ment cases, the Court actually counts the government interests twice, most egregiously im defining the right, and then, compounding the error, when examinimg specific allegations of infrimgements of the diluted right. In many respects, the double-counting evident im $\mathrm{McCleskey}$ distinguishes the Eighth Amendment context from the other categorical cases reviewed above in that in those cases, the categorization ended the analysis with the government prevailing at the definition stage. In the Eighth Amendment, the government imterests serve double duty, imitially dilutimg the right at the definition stage im order to keep the government im Court long enough for it to prevail at the application stage.

\section{Definitional Balancing: Defining Speech}

Defimitional balancing is the preeminent constitutional method practiced today. ${ }^{121}$ Despite its substantial use, the parameters of definitional balancing remaim somewhat obscure. Of course, initially,

120 Id. at 319 ("Legislatures . . . are better qualified to weigh and 'evaluate the results of statistical studies in terms of their own local conditions and with a flexibility of approach that is not available to the courts.' ") (quoting Gregg, 428 U.S. at 186).

121 Aleinikoff, supra note 43, at 943-44. See id. at $944 \mathrm{n} .4$ for a list of sources debating the wisdom of this balancing. 
some constitutional right must be implicated before the Court can review the government action. As the metaphor suggests, the reviewing Court sets the right implicated on one scale and the government reasons for restricting that right on the other. The weightier privilege prevails. The distinguishing feature of the definitional balance is that it is struck at a macro level, with categories of cases being reviewed to determine the requisite degree of constitutional protection. Balancing appeals to the Madisonian structure of accominodation by seeming to account for the rights and imterests of both majority and individual; the scales allow for the rational comparison of conipetimg privileges. In practice, however, the Court has been sloppy in separating the ingredients to be weighed and in failing to clean the scales after each use.

Perhaps the most fertile ground for debatimg categories in the Constitution is the Free Speech Clause of the First Amendment. ${ }^{122}$ The Court's First Amendment jurisprudence is too broad a subject to be covered comprehensively here. This part examimes a discrete area of First Amendment concern-obscenity and pornography. More than most provisions of the Constitution, the practical consequences of transposing the burden of persuasion from government to challenger can be seen clearly in the First Amendment context.

The Free Speech Clause is deceptively simple and straightforward: "Congress shall make no law . . abridging the freedom of speech, or of the press." 123 Taken literally, the First Amendment extends absolute protection to all speech. Justice Hugo L. Black long advocated this absolute or categorical interpretation of the First Amendnient. ${ }^{124}$ His strategy was "absolute," however, only im a narrow sense of that term. Black extended absolute protection to all "speech," but what constituted speech was a matter not susceptible to similarly absolute parameters. In Street $v$. New York, ${ }^{125}$ for example, a flag burning case, Black dissented front the Court's invocation of the First Amend-

122 See, e.g., Frederick Schauer, Categories and the First Amendment: A Play in Three Acts, 34 Vand. L. Rev. 265 (1981); Pierre J. Schlag, An Attack on Categorical Approaches to Freedom of Speech, 30 UCLA L. Rev. 671 (1983).

123 U.S. Const. amend. I.

124 See, e.g., Hugo L. Black, $A$ Constitutional Faith 45 (1968) ("I simply believe that 'Congress shall make no law' means Congress shall make no law.”); Ducat, supra note 42, at 64-78; Harry Kalven, Jr., Upon Rereading Mr. Justice Black on the First Amendment, 14 UCLA L. Rev. 428, 441-44 (1967).

125394 U.S. 576 (1969). 
ment because the prosecution did not rest on spoken words: "The talking that was done took place 'as an integral part of conduct." "126 In his view, conduct and the words attending that conduct did not constitute "speech" despite their expressive content. ${ }^{127}$ When conduct affected ideas, however, it was protected by a First Amendinent balancing process. ${ }^{128}$ The tension created by adopting an absolute test was reduced through the safety valve of a relativistic definition of speech.

The Court has never subscribed to Black's First Amendment absolutist strategy. Although it has instead employed some form of definitional balancing ${ }^{129}$ to reconcile the desires of inajorities to regulate speech with the rights of imdividuals to speak freely, one fact remains clear: Though subject to being balanced, "speech" receives special protection that "non-speech" does not. As Justice John M. Harlan explained, throughout the Court's First Amendinent jurisprudence, "certain forms of speech, or speech in certain contexts, has been considered outside the scope of constitutional protection."130 The process of deciding what forms of speech and which contexts fall outside the First Amendinent illustrates well the reciprocity of definition and application.

In Roth v. United States, ${ }^{131}$ the Court held that "obsceinty is not within the area of constitutionally protected speech or press." 132 In accordance with traditional primciples, the Court mitially based this conclusion on the content of the First Ainendment: "[I] inplicit in the

126 Id. at 610 (Black, J., dissenting) (quoting Giboney v. Eınpire Storage \& Ice Co., 336 U.S. 490, 498 (1949)).

127 See also Black, supra note 123, at 54 ("Conduct" such as "[m]arching back and forth, though utilized to coinmunicate ideas, [was] not speech and therefore [was] not protected by the First Amendinent.").

128 See, e.g., Black, supra note 123, at 60-61 (restating that laws regulating conduct were subject to First Amendinent scrutiny "by a balancing process, if they indirectly affect ideas" ") (quoting Barenblatt v. United States, 360 U.S. 109, 142 (1959) (Black, J., dissenting)).

129 The specific constitutional inethod einployed in the Court's obscenity cases reinains difficult to specify, but inost cases appear to fall into a definitional balancing mode.

130 Konigsberg v. State Bar, 366 U.S. 36, 50 (1961); see also Schauer, supra note 3, at 905 ("No matter what approach is taken, soine definition of speech that will give the First Amendment discrete application and ineaning is required.").

131354 U.S. 476 (1957).

132 Id. at 485. 
history of the First Amendment is the rejection of obscenity as utterly without redeeming social importance."133

[Thirteen] of the 14 States which by 1792 had ratified the Constitution ... provided for the prosecution of hibel, and all of those States made either blasphemy or profanity, or both, statutory crimes. . . .

In light of this history, it is apparent that ... obscemity, [like libel], was outside the protection intended for speech and press. ${ }^{134}$

This historical argument, however, suffers many weaknesses. If it alone supported exclusion of obscemity from First Amendment protection, profanity and blasphemy too should be excluded. But the Court has not, and is not likely to, read this history so conclusively. ${ }^{135}$ Yet, the Roth Court offered no additional constitutional authority and no elaboration of its definition of speech to support its exclusion of obscenity from coverage. Instead, the Court defined "speech" through balancing: "[Obscene] utterances are no essential part of any exposition of ideas, and are of such slight social value as a step to truth that any benefit that may be derived from them is clearly outweighed by the social interest in order and morality."136

The exact relevance of the "social interest in order and morality" in First Amendment obscenity analysis remains obscure. This argument seems to have hittle significance to any definition of speech, yet it also seems to be used to narrow "speech" so as not to extend it to "obscene speech." The Roth Court weighed the social interest against the First Amendment principle, yet there is no First Amendment principle inphicated if obscenity is not speech. If the First Amendment fails to encompass obscenity, the Court has no business reviewing the basis for the government's action. If obscenity is "speech," the Court should not accept uncritically the social interest at stake. The Court, in fact, advanced the "social interest in order and moral-

133 Id. at 484.

134 Id. at $482-83$.

135 Professor Kalven made this point when he asked rhetorically, "Is it clear, for example, that blasphemy can constitutionally be made a crime today? And what would the Court say to an argument along the same lines appealing to the Sedition Act of 1798 as justification for the truly liberty-defeating crime of seditious libel?" Harry Kalven, Jr., The Metaphysics of the Law of Obscenity, 1960 Sup. Ct. Rev. 1, 9. As for Kalven's query regarding seditious libel, the Court has answered it in the negative. See New York Times Co. v. Sullivan, 376 U.S. 254 (1964).

136 Roth, 354 U.S. at 485 (emphasis omitted) (quoting Chaplinsky v. New Hampshire, 315 U.S. 568, 572 (1942)). 
ity" to define speech. By "defining" obscenity out of the category of speech, the Court avoided having to review closely the factual basis for state regulation in this area. ${ }^{137}$ As we will see, n1oreover, this factual basis is particularly troubling in the area of obscenity.

Underlying noodern obscenity doctrine, and the basis for most state regulations, is concern over the effect obscene niaterial has on those reading or viewing it. ${ }^{138}$ Social scientists have long studied and debated the effects of obscenity and pornographic materials on viewers and can be expected to contnue examining this issue for some time to conie. ${ }^{139}$ As two national commissions have discovered, the empirical uncertainties in this area are overwhelming. ${ }^{140}$ The present concern is not the proper resolution to this debate, however, but rather the Court's treatinent of the debate itself. Lacking a consensus regarding the societal effects of obscenity, the party bearing the burden of persuasion inevitably loses. ${ }^{141}$ The result of the Court's First

137 The Roth Court understood the practical effect of its adjudicatory method:

It is insisted that the constitutional guaranties are violated because convictions may be had without proof either that obscene material will perceptibly create a clear and present danger of antisocial conduct, or will probably induce its recipients to such conduct. But, in light of our holding tlat obscenity is not protected speech, the complete answer to this argument is ... [that] "it is unnecessary ... for us ... to consider the issues behind the phrase 'clear and present danger.' "

354 U.S. at 486 (quoting Beauharnais v. Illnois, 343 U.S. 250, 266 (1952)) (footnotes omitted).

138 See, e.g., Paris Adult Theatre I v. Slaton, 413 U.S. 49, 58 (1973) ("[T]here is at least an arguable correlation between obscene material and crime.").

139 For good comprehensive reviews of the research on the effects of pornography, sec Edward Donnerstein, Daniel Linz \& Steven Penrod, The Question of Pornography: Research Findings and Policy Implications (1987); Pornography and Sexual Aggression (Neil M. Malamuth \& Edward Donnerstein eds., 1984).

140 Coinunission on Obscenity and Pornography, Report (1970) [hereinafter 1970 Report]; Attorney Gen.'s Comm'n on Pornography, Final Report (1986) [hereinafter Attorney General's Report]. The Attorney General's Report, though recognizing ambiguities in the researcl, believed the data to be sufficient to support government regulation of most kinds of obscenity and pornograplyy. Attorney General's Report, supra, at 322-51. The Commission's inethods and conclusions, however, have been subjected to trenchant criticism. See Daniel Linz, Steven D. Penrod \& Edward Donnerstein, The Attorney General's Commission on Pornograply: The Gaps Between "Findings" and Facts, 1987 Am. B. Found. Res. J. 713; Richards, supra note 25 .

141 Professor Richards observed that the Attorney General's Report proceeded upon the questionable assumption that the burden lies upon the challenger of state regulations: "[U]nder the Commission's theory of burden of proof, only some small amount of evidence of causal significance is required for the state to continue exercising state power in attacking harms, whereas a strong case of no harms is required to justify publication." Richards, supra note 25 , at 305. But see Attorney General's Report, supra note 139, at 306-09 (discussing the difficulty of establishing the appropriate standard). The Colnmission's allocation of burdens is not 
Amendment jurisprudence has been to place the burden squarely on the challenger of state action.

Paris Adult Theater I v. Slaton ${ }^{142}$ illustrates well the deference the Court pays to the government's interest in the social and moral order by classifying obscenity as other than speech: "It is not for us to resolve empirical uncertainties underlying state legislation, save $\mathrm{m}$ the exceptional case where that legislation plainly impinges upon rights protected by the Constitution itself." 143 But the very conclusion that obscene speech is not an "exceptional case" protected by the Constitution hinges on the "empirical uncertainties" underlying the state legislation. The great ambiguity infecting this area and the extraordinary difficulty in researching these issues means that the state would have considerable difficulty demonstrating the relationship between obscenity and any specific social ills if required to do so. The government's task, therefore, is made highter: "The sum of experience . . . affords an ample basis for legislatures to conclude that a sensitive, key relationship of human existence, central to family life, community welfare, and the development of human personality, can be debased and distorted by crass commercial exploitation of sex." 144 In determining that the First Amendment does not extend to obscemity, the Court defers to anecdotal experience to uphold the basis for the state's action. In marked contrast, when regulations fall within the core of the First Amendment, the state ordmarily bears a substantial burden of justifying its mterference with that right. In the context of obscenity, the Court avoids placing this unbearable empirical burden on the state by employing these very same "empirical uncertamties" to categorize obscenity as nonspeech. This, of course, has the effect of shifting the obligation to resolve these uncertainties onto the challenger of the state action.

The Court's recent decision in Barnes v. Glen Theatre, Inc. ${ }^{145}$ illustrates the danger created by the Court's definition of "speech." In Glen Theatre, petitioner challenged an Indiana law barring public

questionable in regard to obscenity in light of Roth and Paris Adult Theater I; however, the Commission's conclusions extended well beyond obscenity to include pornography-materials receiving First Amendment protection. See id. at 299-302.

142413 U.S. 49 (1973).

143 Id. at 60.

144 Id. at 63.

145111 S. Ct. 2456 (1991) (plurality opinion). 
nudity as applied to nude dancing in the petitioner's club. Chief Justice Rehnquist, joined only by Justice O'Connor and Justice Anthony $M$. Kennedy, found that "nude dancing of the kind sought to be performed here is expressive conduct within the outer perimeters of the First Amendinent, though we view it as only inarginally so."146 Rehnquist did not explain his narrow interpretation of speech on the basis of First Amendment principles. He, instead, enlisted government purposes to fix the appropriate level of protection for this form of speech: '[W] hen 'speech' and 'nonspeech' elements are combined in the saine course of conduct, a sufficiently important governmental interest in regulating the nonspeech element can justify incidental limitations on First Amendment freedoins."147 This "sufficiently important governmental interest," it turns out, was the "authority to provide for the public health, safety, and morals"-precisely the saine justification given for regulating obscenity in Roth. ${ }^{148}$ Rehnquist applied in theory an intermediate level of scrutiny-that the government interest must be "important or substantial"-but apphed in fact the saine minimal standard einployed when the First Amendment is not implicated. ${ }^{149}$

In effect, Glen Theatre, in which the First Amendment was imphcated, was indistinguishable froin the Court's obscenity cases, in which the First Amendment was deemed not to be implicated. ${ }^{150}$ The

146 Id. at 2460 (plurality opinion).

147 Id. at 2461 (plurality opinion).

148 Id. at 2462 (plurality opinion).

149 Justice Scalia, concurring, was more explicit about the absence of First Amendment protection in the nude dancing context on the basis that "the challenged regulation ... [is] a general law regulating conduct and not specifically directed at expression." Id. at 2463 (Scalia, J., concurring). Scalia advanced the same government interests argument used in Smith to define the parameters of the Frec Exercise Clause: "The government's ability to enforce generally applicable prohibitions of socially harmful conduct, like its ability to carry out other aspects of public policy, "cannot depend on measuring the effects of a governmental action on a religious objector's spiritual development." '" Id. at 2467 (Scalia, J., concurring) (quoting Employment Div., Dep't of Human Resources of Oregon v. Smith, 110 S. Ct. 1595, 1603 (1990) (quoting Lyng v. Northwest Indian Cemetery Protective Ass'n, 485 U.S. 439, 451 (1988))).

150 Justice Scalia came to the same conclusion:

It cannot reasonably be demanded . . . that every restriction of expression incidentally produced by a general law regulating conduct pass normal First-Amendment scrutiny, or even -as some of our cases have suggested-that it be justified by an important or substantial' government interest. Nor do our holdings require such justification: we have never invalidated the application of a general law simply because the conduct that 
facile transference of government interests from the application prong to the definition prong made this result possible. Nude dancing, Rehnquist conceded, constituted "speech," so the pertinent inquiry involved the apphication of that imterpretation to the government's interests. Because the "social imterest in order and inorality" served in the early cases to define obscemity as nonspeech, this government purpose could be einployed by Rehnquist in Glen Theatre both to narrow the definition of the right (i.e., placing nude dancing at the "1nargins" of speecli) and, in addition, to outweigh expression that was speecli. Relinquist thus double counted the government interest in social order and morality in Glen Theatre.

Justice David H. Souter, in contrast, recoginzed tlie need to add factors to the government's side of the scales if the governinent's interests were to now outweigh an infringed riglit. Agreeing that the nude dancing at issue was expressive conduct deserving of First Amendment coverage, Souter wrote separately to supply an additional basis for the regulation beyond "society's moral views": "[T]lie statute is applied to nude dancing because such dancing 'encourag[es] prostitution, increas[es] sexual assaults, and attract[s] other criminal activity." "151 Altlough the inajority's moral desires iniglit outweigh obscenity, standing alone they could not outweigh "speecl,," lowever far out on the perimeter of the First Amendinent it might be situated. ${ }^{152}$ Although the actual burden Souter placed on the governinent was quite sliglit, ${ }^{153}$ his opinion, like Justice O'Connor's opinion in Smith, is faithful to Madisomian premises, and tlius does not contain the potential for harn inherent in Relinquist's opinion.

it reached was being engaged in for expressive purposes and the government could not demonstrate a sufficiently important state interest.

Id. at 2466 (Scalia, J., concurring) (citation omitted).

151 Id. at 2469 (Souter, J., concurring) (quoting Brief for Petitioners 37).

152 Justice Harlan put it this way: "[T]he mere assertion that the action of the State finds justification in the controversial realm of morals cannot justify alone any and every restriction it imposes." Poe v. Ullman, 367 U.S. 497, 545 (1961) (Harlan, J., dissenting).

153 In concluding that the government's interest was important or substantial, Souter deferred to the state's empirieal judgment. Souter explained that, just as in Renton v. Playtime Theatres, Inc., 475 U.S. 41 (1986), the state

[is] not compelled to justify its restrictions by studies specifically relating to the problems that would be caused by adult theaters in that city. Rather, "[the city] was entitled to rely on the experiences of . . . other cities" which demonstrated the harmful secondary effects correlated with the presence "of even one [adult] theater in a given neighborhood." 


\section{3. $\quad$ Multitiered Balancing Tests}

Multitiered tests theoretically sit very near definitional balancing on the spectrum of constitutional methods. Definitional balancing informs the construction of the mdividual right, but this result, rather than being apphed inexorably like the definitional balance, is balanced once again in a quasi-ad hoc fashion. All of this balancing makes the reader, and apparently the Court too, quite dizzy.

\section{a. The Equal Protection Clause}

In many respects, the Equal Protection Clause is the exemplar of the meeting of interpretation and apphication in constitutional adjudication. ${ }^{154}$ For this reason, it embodies many of the attendant coniplications that this juncture has engendered. Court decisions and scholarly commentary in this domain are especially solicitous of the principles behind the shifting burdens of persuasion inherent in the constitutional structure. ${ }^{155}$ Because of conceru over regressing into the Lochnerian bog, equal protection jurisprudence-the last bastion of substantive rights protection ${ }^{156}$-is sensitive to the majoritarian foundations of the system. Still, im a wide variety of areas, the Court has not shied away froin subjecting the actions of the political branches to close scrutiny when core rights were at risk. Identifying the parameters of the Equal Protection Clause's core, however, has proved difficult, leading the Court to borrow elements of the application prong for assistance.

In Graham v. Richardson, ${ }^{157}$ the Court interpreted the Equal Protection Clause to extend to aliens, finding them to be a "discrete and

Glen Theatre, 111 S. Ct. at 2469 (Souter, J., concurring) (third alteration in original) (citation omitted) (quoting Renton v. Playtime Theaters, Inc., 475 U.S. 41, 50-51 (1986)).

Souter thus required the state to articulate the harmful secondary effects that served as the basis for its regulation of nude dancing but left the burden for introducing research to refute this empirical claim to the challenger of state action. Heightened scrutiny for Souter amounted to a heightened pleading requirement.

154 See generally Monahan \& Walker, supra note 15, at 581-82 (focusing on judicial review under the Equal Protection Clause to "illustrate how courts should deal with unanswered empirical questions" in constitutional interpretation generally).

155 See, e.g., id. at 582-89.

156 See Lewis F. Powell, Jr., Carolene Products Revisited, 82 Colum. L. Rev. 1087, 1089-91 (1982).

157403 U.S. 365 (1971). 
insular' mmority." 158 Under this interpretation, laws singling out aliens for unfavorable treatment were "subject to strict judicial scrutiny." 159 In Graham and subsequent cases, the Court apphied strict scrutiny to invalidate laws discriminating against aliens in regard to receiving welfare benefits, ${ }^{160}$ employment in the civil service, ${ }^{161}$ state bar certification, ${ }^{162}$ employment as a civil engineer, ${ }^{163}$ and financial assistance for higher education. ${ }^{164}$ In each of these cases, the asserted government purpose for classifying aliens for discriminatory treatment withered under strict scrutmy review. ${ }^{165}$

In Foley v. Connelie, ${ }^{166}$ however, the Court qualified its interpretation of the protection accorded aliens. ${ }^{167}$ The Foley Court upheld a New York law that excluded ahens from public einployment as state troopers, on the grounds that those positions involved the establishment and exercise of broad public policy. ${ }^{168}$ But the Court did not scrutinize the law strictly either to determine whether this was in fact true, or if it was, to determine if that fact created a compelling imterest in excluding aliens sufficient to withstand strict scrutiny review. Instead, the Court carved an exception to the coinpelling interest test for "those 'miportant nonelective executive, legislative, and judicial positions,' held by 'officers who participate directly in the formulation, execution, or review of broad public policy." "169 The basis for this exception, and im fact the rationale for the New York law, was the citizenry's desire to "be governed by their citizen peers." 170 The right of aliens as a class to receive equal protection of the laws was thus

158 Id. at 372.

159 Id. at 376. See generally supra notes 58-60 and accompanying text (introducing the three tiers of equal protection scrutiny and the types of interest which generally trigger each tier).

160 Graham, 403 U.S. 365.

161 Sugarman v. Dougall, 413 U.S. 634 (1973).

162 In re Griffiths, 413 U.S. 717 (1973).

163 Examining Bd. of Engineers, Architects \& Surveyors v. Flores de Otero, 426 U.S. 572 (1976).

164 Nyquist v. Mauclet, 432 U.S. 1 (1977).

165 See Elizabeth Hull, Resident Aliens and the Equal Protection Clause: The Burger Court's Retreat from Graham v. Richardson, 47 Brook. L. Rev. 1 (1980).

166435 U.S. 291 (1978).

167 This change in direction was anticipated in dicta in Sugarman v. Dougall, 413 U.S. 634, 647 (1973). See Hull, supra note 164, at 15.

168 Foley, 435 U.S. at 293.

169 Id. at 296 (quoting Sugarman, 413 U.S. at 647).

170 Id. 
narrowed by the coinpeting government interest in excluding noncitizens froin political positions. After Foley, the remnants of the equal protection right, previously recognized as a core value inandating strict scrutiny, accorded aliens inerely rational basis review of the goverument's purposes in particular contexts. ${ }^{171}$

The governinent interest in the political function inight indeed be sufficiently coinpelling to outweigh aliens' rights under the Equal Protection Clause, but the Court never reached this conclusion. The Court never examined the effect of alien inclusion on the political function; nor did it scrutinize the public's expressed desire to exclude aliens froin the political function. It sinply shifted the burden to the alien to deinonstrate the irrational basis for excluding ahens from certain occupations, or for classifying those occupations as "political."172 Moreover, the Court never examined, and itself seemed to assume, what Justice Stevens called the aliens' "unarticulated characteristic," 173 that they are less loyal than citizens. Altlough the Court might have reaclied the same result applying strict scrutiny, such analysis would have placed a real burden on the state to prove, rather than assuine, its case.

Alternatively, perhaps a "correct" interpretation of the Equal Protection Clause does not prescribe a "coinpelling interest" test when the rights of ahens are inplicated. The Court, however, never reconsidered the "constitutional" meaming of the clause. Instead, the rights created by that clause became less "fundamental" by virtue of the inportance of the government's concerns in the political function context. The Court reinoved any burden from the state to explain its reasons for discriminating against aliens by einploying those very reasons to define the right at stake.

171 Id. ("The State need only justify its classification by a showing of some rational relationship between the interest sought to be protected and the limiting classification.").

172 As the separate dissents make clear, finding police officers to qualify within the newly created political function category could pass muster only under the most minimal review. See id. at 304-05 (Marshall, J., dissenting) ("The officer responding to a particular situation is only applying the basic policy choices-which he has no role in shaping - to the facts as he perceives them."); Id. at 310 (Stevens, J., dissenting) ("Respect for the law enforcement profession and its essential function, like respect for the military, should not cause us to lose sight of the fact that in our representative democracy neither the constabulary nor the military is vested with broad policymaking responsibility.").

173 Id. at 312 (Stevens, J., dissenting); see also Hull, supra note 164, at 21 (finding Justice Stevens' focus on the "unarticulated characteristic" correct). 


\section{b. The Due Process Clause}

In Roe v. Wade, ${ }^{174}$ the Court found that "[the constitutional] right of privacy . . . is broad enough to encompass a woman's decision whether or not to terminate her pregnancy."175 This fundamental right has since been firmly located in the Due Process Clause of the Fourteenth Amendment. Justice Blackmun, writing for the Roe Court, held that the Texas law prohibiting abortion could be upheld only if it served a compelling state interest. ${ }^{176}$ The identified right was supported by a variety of arguments, mcludimg especially the social and psychological effects of an unwanted pregnancy on a woman. ${ }^{177}$ Since Roe, the right has been redescribed in several ways, and the fundamental nature of the right is today in serious doubt. ${ }^{178}$

Although the "essential holding" of Roe was reaffirmed by a majority of the Court just last term in Planned Parenthood v. Casey, ${ }^{179}$ the statement of the law has changed significantly since 1973. Originally, Roe identified the decision to terminate a pregnancy as a fundamental right and subjected state laws limitimg that right to the most exacting scrutiny of the compelling interests test. ${ }^{180}$ Under this test, the state assumes the burden of justifying any infringements of the right. Since Roe, members of the Court have advanced several substantial modifications both of the right to privacy, and its attendant level of scrutiny.

Only one Justice continues to subscribe to Roe in all its particulars-Justice Blackmun, its author. ${ }^{181}$ Four Justices question the foundation of Roe itself and deny that the right to an abortion is fun-

\footnotetext{
174410 U.S. 113 (1973).

175 Id. at 153.

176 Id. at 155.

177 Id. at 153.
}

178 See generally Daniel A. Farber \& John E. Nowak, Beyond the Roe Debate: Judicial Experience with the 1980's "Reasonableness" Test, 76 Va. L. Rev. 519, 533-34 (1990) (exploring alternative interpretations of Roe); Nadine Strossen, Recent U.S. and International Judicial Protection of Individual Rights: A Comparative Legal Process Analysis and Proposed Synthesis, 41 Hastings L.J. 805, 871-72 (1990) (exploring the use of international human rights principles in our democratic legal process).

179112 S. Ct. 2791 (1992).

180 Roe v. Wade, 410 U.S. 113, 155 (1973); see also Akron v. Akron Center for Reproductive Health, 462 U.S. 416, 427 (1983) (citing Roe), overruled by Casey, 112 S. Ct. 2791.

181 Casey, 112 S. Ct. at 2844 (Blackmun, J., concurring in part and dissenting in part). 
damental. ${ }^{182}$ Four Justices, and two different approaches to the issue, occupy the broad middle ground between a "fundamental right" and no right. Justice Stevens has consistently scrutinized abortion regulations closely but does not embrace fully the strictures of Roe ${ }^{183}$ The second approach occupying the middle ground, one long advanced by Justice O'Connor, protects a woman from state laws that "unduly burden" the decision whether to terminate a pregnancy. ${ }^{184}$

In somewhat modified form, O'Connor's nndue burden test became the operative analysis in abortion cases with Justices Kennedy's and Souter's embrace of it in Casey. In a rare joint opinion, Justices O'Connor, Kennedy, and Souter held that when a "state regulation imposes an undue burden on a woman's ability to [procure an abortion] ... the power of the State reach[es] into the heart of the liberty protected by the Due Process Clause." 185 The level of review the undue burden test requires, however, remains unclear. According to the joint opinion, "[a] finding of an undue burden is a shorthand for the conclusion that a state regulation has the purpose or effect of placing a substantial obstacle in the path of a woman seeking an abortion of a nonviable fetus."186 This strongly empirical test results from a compromise struck at the definition stage of analysis between a woman's right to an abortion and the government's interests in inater-

182 Justice White, Justice Scalia, and Justice Clarence Thomas joined Chief Justice Rehnquist in rejecting Roe:

We think . . . both in view of this history and of our decided cases dealing with substantive liberty under the Due Process Clause, that the Court was mistaken in Roe when it classified a woman's decision to terminate her pregnancy as a "fundamental right" that could be abridged only in a manner which withstood "strict scrutiny."

Id. at 2860 (Rehnquist, C.J., concurring in part and dissenting in part).

183 See, e.g., Hodgson v. Minnesota, 110 S. Ct. 2926, 2944 (1990) (upholding a 48-hour delay of a minor's abortion decision because "there is no evidence that the 48-hour period itself is unreasonable"). In the abortion context, Justice Stevens adopts a relatively light standard of review but puts the burden on the state to demonstrate a rational basis for its regulation. In Hodgson, for example, he stated:

Because the Minnesota statute unquestionably places obstacles in the pregnant minor's path to an abortion, the State has the burden of establishing its constitutionality. Under any analysis, the Minnesota statute cannot be sustained if the obstacles it imposes are not reasonably related to legitimate state interests.

Id. at 2937. Arguably, in abortion eases, Stevens has put teeth into the rational basis test.

184 Id. at 2949-50 (O'Connor, J., concurring in part and concurring in the judgment); Webster v. Reproductive Health Services, 492 U.S. 490, 530 (1989) (O'Connor, J., concurring in part and concurring in the judgment); Akron, 462 U.S. at 453 (O'Connor, J., dissenting).

185 Casey, $112 \mathrm{~S}$. Ct. at 2819 (plurality opinion).

186 Id. at 2820 (plurality opinion). 
nal health and the hife of the fetus. As a result of this definitional compromise, analysis at the application stage has proved to be difficult. Before exanining the application of the test, however, it is instructive to exanine its definitional origins.

In Akron v. Akron Center for Reproductive Health, lier most expansive discussion of the undue burden test prior to Casey, O'Connor disparaged application of a conıpllinig interest test in tlie abortion context: " "[A] test so severe that legislation rarely can meet it should be imposed by courts with deliberate restraint in view of the respect that properly should be accorded legislative judgments." "187 This statenient miscomprehends the essence of traditional fundamental rights analysis, for when legislative action infringes a fundamental riglit, the Court is obliged to scrutinize strictly the legislature's judgment. ${ }^{188}$ But according to O'Connor, the "nature and scope" of the abortion right render it particularly appropriate for tle "unduly burdensome" test. ${ }^{189}$ O'Connor, liowever, never explained why the nature and scope of the right narrows the Court's scrutiny. Instead, slie rested her interpretation of the parameters of the riglit on the gravity of tlie government's interests in niaterual healtlı and potential life. ${ }^{190}$ The undue burden test defines the riglit of reproductive clioice priniarily in terms of the governnient's purposes in the n1atter. ${ }^{191}$ In actuality, the right is diluted at the definition stage by the govern-

187 Akron, 462 U.S. at 463 (O’Connor, J., dissenting) (alteration in original) (quoting Carey v. Population Servs. Int'l, 431 U.S. 678, 705 (1977) (Powell, J., concurring in part)).

188 See Susan R. Estrich \& Kathleen M. Sullivan, Abortion Politics: Writing for an Audience of One, 138 U. Pa. L. Rev. 119, 124 (1989) ("Standard constitutional practice requires applying strict scrutiny to government restrictions on fundamental rights.").

189 Akron, 462 U.S. at 463 (O'Connor, J., dissenting).

I90 Id. at 460 (O'Connor, J., dissenting).

191 Justice O'Connor would almost certainly object to this characterization of the unduly burdensoine test. Indeed, then-Solicitor General Rex E. Lee argued in Akron that the unduly burdensome test should "accord heavy deference to the legislative judginent" of what restrictions constitute "undue burdens." O'Connor disagreed:

The "unduly burdensome" standard is appropriate not beeause it incorporates deference to legislative judgment at the threshold stage of analysis, but rather because of the limited nature of the fundainental right that has been recognized in the abortion cases. ... [I]t is not appropriate to weigh the state interests at the threshold stage.

Id. at 465 n.10 (O'Connor, J., dissenting) (citation omitted) (discussing amicus curiae brief for the United States). Despite O'Connor's description of her method, her opinion is devoid of any constitutional authority that supports her arguinent that the nature of the privacy right is less in abortion cases. The government interests might not be explicitly weighed at the threshold stage, but they siguificantly affect the categorization at that stage. 
ment's interests, not by any particular understanding of the right of privacy in the abortion context. ${ }^{192}$ In practice, this merger of rights and interests has meant that no clear burden is allocated between the parties to prove, or disprove, the fact that the regulation operates as a "substantial obstacle" to the exercise of the right.

The recent decision in Casey illustrates well the ambiguity created over which party bears the burden of proof on the factual (and normative) questions that inevitably arise under the undue burden test. Among other provisions, the Pennsylvania law challenged in Casey contained a 24-hour waiting period and a spousal notification requirement. ${ }^{193}$ The joint opinion upheld the former and invalidated the latter, despite the findings of the district court below that both provisions unconstitutionally interfered with the decision whether to terminate a pregnancy. ${ }^{194}$ The district court found that the 24-hour waiting period mcreased the cost and risk of abortions, and was therefore "particularly burdensome." 195 The joint opinion, however, concluded, "on the record before us ... we are not convinced that the 24hour waiting period constitutes an undue burden." 196 The 24-hour waiting period, despite its particularly burdensoine nature, was not a sufficiently substantial obstacle to be unduly burdensome. Apparently, the challengers bore, and failed to meet, the burden of persuasion on this matter. ${ }^{197}$

192 Dissenting in Hodgson, Justice Marshall well understood the sleight of hand that the unduly burdensome test accomplished. Marshall argued that the right should be assessed against the government interests, not diluted by those interests: "Neither the scope of a woinan's privacy right nor the maguitude of a law's burden is dinninished because a woinan is a minor. Rather, a woman's ininority status affects only the nature of the State's interests." Hodgson v. Minnesota, 110 S. Ct. 2926, 2952 (1990) (Marshall, J., dissenting in part).

193 The other three sections of the Act, all upheld by the Court, included an informed consent provision, a provision requiring that ininors obtain parental consent that also contained a judicial bypass procedure, and certain reporting requirements for facilities providing abortion services. Planned Parenthood v. Casey, 112 S. Ct. 2791, 2803 (1992).

194 Planned Parenthood v. Casey, 744 F. Supp. 1323, 1396 (E.D. Pa. 1990), affd in part and rev'd in part, 947 F.2d 682 (3d Cir. 1991), aff'd in part and rev'd in part, 112 S. Ct. 2791 (1992).

195 Id. at 1352.

196 Casey, 112 S. Ct. at 2826 (plurality opinion).

197 The joint opinion also placed the burden of proof to show a "substantial obstacle" on the challenger when it upheld the other three sections of the statute. In upholding the informed consent provision, the joint opinion reasoned that there "is no evidence on this record that [this requirement] ... would anount in practical terms to a substantial obstacle to a woman seeking an abortion." Id. at 2824 (plurality opinion). Sinilarly, the joint opinion upheld the reporting requirements, because "there is no... showing on the record before us" that they 
In marked contrast, the Court adopted the factual findings of the district court in striking down the spousal notification provision. The Court listed an array of scholarly research it believed indicated that "[t]he spousal notification requirement ... does not merely make abortions a little more difficult or expensive to obtaim; for many women, it will impose a substantial obstacle."198 In fact, the Court went beyond the findings of the district court and cited research not contained in the record to support its conclusion. The joint opinion leaves the distinct impression that the government bore the burden of persuasion to demonstrate that spousal notification would not constitute a substantial obstacle. The government did not meet this burden.

The undue burden test leaves individual judges free to choose what facts to accept or reject. In this respect, the undue burden test resembles ad hoc balancing, examined in the next Section. In ad hoc balancing cases, the balance is conducted in the application prong after a determmation that the Constitution is implicated. Although in theory this approach imglit conform to Madisonian principles, ${ }^{199}$ in practice, the Court has found facts in these cases selectively. In Casey, the jomt opinion balanced government interests and the riglit of reproductive choice in the definition prong in order to frame a test that leaves the Court still finding facts at their pleasure. Althougli prospective remedies miglit differ, the effect of the two approaches has been the same. Justice Scalia lamented this muddled state of affairs:

[T] he approach of the joint opinion is, for the most part, simply to highlight certain facts in the record that apparently strike the three Justices as particularly significant in establishing (or refuting) the

constitute a "substantial obstacle" to abortion decisions. Id. at 2833 (plurality opinion). Finally, the joint opinion summarily upheld the parental consent provision relying on Hodgson. Id. at 2833 (plurality opinion). In Hodgson, Justice O'Connor found no evidence demonstrating that the parental consent provisions, with a judicial bypass procedure, would create an undue burden, despite the district court's conclusion to the contrary. Compare Hodgson, 110 S. Ct. at 2951 (O'Connor, J., concurring in part and concurring in the judgment in part) with the district court opinion in Hodgson v. Minnesota, 648 F. Supp. 756, 778 (D. Minn. 1986), aff'd, 827 F.2d 1191 (8th Cir.), cert. denied, 479 U.S. 1102 (1987) (finding that the two-parent notice requirement, even with the judicial bypass procedure, "affirmatively discourages parent-child communication"). See also Akron v. Akron Ctr. for Reproductive Health, 462 U.S. 416, 466 (1983) (O'Connor, J., dissenting) (noting failure to introduce evidence showing that a particular abortion restriction constituted an "undue burden"), overruled by Casey, 112 S. Ct. 2791.

198 Casey, 112 S. Ct. at 2829.

199 See infra notes 228-32 and accompanying text. 
existence of an undue burden; after describing these facts, the opinion then simply announces that the provision either does or does not impose a "substantial obstacle" or an "undue burden."200

By juinbling the individual right and government interests at the definition stage to create the undue burden test, the Court divests the application prong of a guiding principle. For the Justices at the inethodological poles of the Court, factual questions at the apphication stage can be resolved straightforwardly because the defintion stage provides them with such a guide. Justice Blackmun, who believed the right to be fundamental, found that the state did not come close to meeting the compelling interest standard on the evidence available. ${ }^{201}$ At the opposite pole, Chief Justice Relinquist, joined by Justice White, Justice Scalia, and Justice Clarence Thomas, found the evidence available to be insufficient to conclude that the state had acted irrationally. ${ }^{202}$ Although less straightforward, Justice Stevens' analysis makes clear that a middle position can be framed that establishes a constitutional principle in the definition prong that guides even close cases in the application prong. ${ }^{203}$ The disturbing feature in the joint opinion's middle position is what Justice Scaha called its "rootless nature."204 In incorporating government interests in the defimition of the right, the joint opinion unearthed the right of reproductive choice from the constitutional soil. It is not dead yet; but it desperately needs tending.

\section{Ad Hoc Balancing}

Although typically thought of as a "shoot-from-the-hip" methodology, ad hoc balancing is rarely "ad hoc." In the many contexts in which it is used, ad hoc balancing is guided by principles and precedent that himit the discretion of the balancing judge. Furtherinore, the ad hoc balance is triggered by, and thus is dependent upon, the definition prong of constitutional adjudication.

Unlike the other constitutional methods, in practice ad hoc balancing does not misallocate the burden of persuasion-it simply ignores it. By reducing adjudication to a constitutional calculus, the various

200 Casey, 112 S. Ct. at 2880 (Scalia, J., concurring in part and dissenting in part).

201 Id. at 2853-54 (Blackmun, J., concurring in part and dissenting in part).

202 Id. at 2867-73 (Rehnquist, C.J., concurring in part and dissenting in part).

203 Id. at 2840-41 (Stevens, J., concurring in part and dissenting in part).

204 Id. at 2878 (Scalia, J., concurring in part and dissenting in part). 
rights and interests are inserted into the Court's balancing formula, with neither side bearing explicit responsibility for deinonstrating the relevant facts. The parties are equally responsible for arguing facts, and ambiguity is not autoinatically resolved in favor of one party or the other. Ambiguity, to the extent it is adinitted, merely becoines a part of the calculation.

\section{a. Procedural Due Process}

Mathews v. Eldridge $e^{205}$ stands as the paradigmatic ad hoc balancing decision. ${ }^{206}$ In Mathews, the respondent claimed that due process required an opportumity for an evidentiary hearing prior to the termination of Social Security disability benefits. ${ }^{207}$ The state conceded that a property interest was at risk and thus that the Due Process Clause was implicated. The state argued, however, that due process did not inandate an evidentiary hearing. The Court observed that " '[d]ue process is flexible and calls for such procedural protections as the particular situation deınands." "208 The Court then set forth the three factors that must be balanced in each case:

First, the private interest that will be affected by the official action; second, the risk of an erroneous deprivation of such interest through the procedures used, and the probable value, if any, of additional or substitute procedural safeguards; and finally, the Government's interest, including the function involved and the fiscal and admimistrative burdens that the additional or substitute procedural requirement would entail. ${ }^{209}$

Although usually described as ad hoc, the Mathews balancing formula is rarely apphied in a truly ad hoc fashion. The Court uses the test to resolve entire categories of cases rather than to reconcile the conflicting interests in any particular case. In fact, in Mathews itself, the Court did not consider how the discontinuance of disability benefits would affect Eldridge. ${ }^{210}$ Instead, the Court applied the Mathews test to the world of disability benefits. Mathews thus reseinbles definitional balancing, albeit at a narrower level of analysis than

205424 U.S. 319 (1976).

206 See Aleinikoff, supra note 43, at 948 .

207424 U.S. at 325.

208 Id. at 334 (quoting Morrissey v. Brewer, 408 U.S. 471, 481 (1972)).

209 Id. at 335.

210 See id. at 350 (Brennan, J., dissenting). 
the classic examples of definitional balancing. ${ }^{211}$ Still, the general ad hoc method differs considerably from the definitional method-as well as all of the other inethods-in important respects.

As noted, the Mathews balance is apphed only after determining that the Constitution has been infringed. The purpose of the threefactor balancing is to assess the government's justification for that mfringement. Yet, unlike the other constitutional methods already examined, the Mathews test omits any semblance of situating burdens of persuasion. A finding of constitutional infringement imitiates the process of review, but does not give rise to any presumptive outcome. Instead, the test creates a sort of free for all, with the particular right and several imterests heaped upon an uncalibrated scale. ${ }^{212}$ Although the sundry items may be separated for weighing purposes, the specific identity of the parties, whether individual or state, matters very hittle. The state's privilege is weighed equally with the individual's. The Bill of Rights does not erect a bulwark against majority tyranny but, rather, negotiates a settleinent between opposing forces.

In Parham v. J.R. , ${ }^{213}$ for example, the Court held that the Constitution does not require a due process hearing when parents seek to "voluntarily commit" their children to state mental hospitals. Chief Justice Warren E. Burger, writing for the Court, reached this result by examiming the individual and state interests set forth in Mathews. Burger defined "privacy" to incorporate the child's liberty interest but added that the right of privacy also extends to parents who historically have broad authority over ininor children. ${ }^{214}$ The second interest concerned the risk of erroneously depriving the child of his liberty. The third interest implicated the government's primary concern with reducing the obstacles to hospital adınission, in order to allow hospitals to carry out their inission and to avoid discouraging families froin using state inental health facilities. ${ }^{215}$

211 In other contexts, the Court does balance the interests in individual cases in an ad hoc fashion. See, e.g., Maryland v. Craig, 110 S. Ct. 3157 (1990) (calling for balancing the psychological effects to the individual witness against the defendant's confrontation right in determining the constitutionality of one-way video testimony).

212 See Aleinikoff, supra note 43, at 993; see also Ann Woolhandler, Essay, Rethinking the Judicial Reception of Legislative Facts, 41 Vand. L. Rev. 111 , 121 (1988).

213442 U.S. 584 (1979).

214 Id. at 600.

215 Id. at 604-05. 
In reading the result off the scales, however, Burger provided little explanation of the metric by which the scale measured these conflicting interests. Burger did not specify the weightiness of these interests when compared in the abstract, nor did he seriously examine the factual components of these interests when coinpared in the individual case. We do not know, for example, how much value the Constitution attaches to a child's hiberty interest, or the severity of the consequences following an incorrect commitinent, or the state benefit accruing from unfettered admissions to mental hospitals. Moreover, we learn little from Burger's opinion regarding the effect of the deprivation of liberty on this child, the extent to which due process review might increase the accuracy of coinmitinents, or the state benefits derived from increased commitments. ${ }^{216}$ In short, the opinion lists the values implicated by "voluntary" commitments of children seriatim, and summarily reviews the empirical consequences of these coinmitments, without ever truly reconciling these diverse and conflicting factors.

\section{b. The Fourth Amendment}

This Section began with the categorical method so it is fitting that it concludes with the ad hoc balancing of the Fourth Amendment. It is fitting because until relatively recently, the Fourth Amendment was defined categorically. The moderu Court, however, has moved the Fourth Amendment in a short period of time from the categorical pole to the ad hoc pole. ${ }^{217}$ The Fourth Amendment encapsulates in a nutshell the Court's struggle to reconcile individual rights and goverument interests across the spectrum of constitutional methods.

In defining the reach of the Fourth Amendinent, ${ }^{218}$ the Court at first fashioned a categorical framework in which to assess challenged

216 See generally Lois A. Weithorn, Note, Mental Hospitalization of Troublesome Youth: An Analysis of Skyrocketing Admission Rates, 40 Stan. L. Rev. 773 (1988) (discussing the reasons for the sharp increase in admissions of children to mental health facilities and proposed solutions to this "problem").

217 This Section's description of the evolution of Fourth Amendment doctrine owes a significant debt to my colleague Scott Sundby's excellent work. Scott E. Sundby, A Return to Fourth Amendment Basics: Undoing the Mischief of Camara and Terry, 72 Minn. L. Rev. 383 (1988). For another especially insightful analysis of the Fourth Amendment see Nadine Strossen, The Fourth Amendment in the Balance: Accurately Setting the Scales Through the Least Intrusive Alternative Analysis, 63 N.Y.U. L. Rev. 1173 (1988).

218 The Fourth Amendment provides as follows: 
state action. This categorical view focused on the warrant clause of the amendment: "[T]he Court presumed that a warrant based on probable cause was required before the police could perform a search or arrest."219 The reasonableness clause was avoided for fear that its use would result in an ad loc assessment that would take "Fourtl Amendment protection ... [to] the evaporation point."220 In its struggle to maintam the categorical perspective, lowever, the Court confused Madisoman tenets.

In Frank v. Maryland, ${ }^{221}$ for example, the Court considered whether a warrantless inspection of a liouse violated the Fourth Amendment. The Court souglit to maintaim the essential imtegrity of the Fourtlı Amendment by not dispensmg witlı the "rigorous constitutional restrictions" for the issuance of searcli warrants. ${ }^{222}$ Yet at the same time, failure to allow warrantless housing inspections might seriously undermine community lealtl. The Court resolved this conflict "categorically," defining the reach of the amendment as extending only to searches in connection with criminal prosecutions. But Justice Felix Frankfurter's explanation of this definitional limitation reads like classic government interests analysis:

Time and experience have forcefully taught that the power to imspect dwelling places, eitler as a matter of systematic area-by-area search or, as here, to treat a specific problem, is of indispensable importance to the maintenance of community healtli; a power that would be greatly hobbled by the blanket requirement of the safeguards necessary for a search of evidence of criminal acts. ${ }^{223}$

The Frank Court's conclusion that the Fourtl Amendment was not infringed by housing inspections was reconsidered and rejected in Camara v. Municipal Court. ${ }^{224}$ Justice White dismissed the "rather reinarkable premise" that lousing inspections did not fall within the

The right of the people to be secure in their persons, houses, papers, and effects, against unreasonable searches and seizures, shall not be violated, and no Warrants shall issue, but upon probable cause, supported by Oath or affirmation, and particularly describing the place to be searched, and the persons or things to be seized.

U.S. Const. amend IV.

219 Sundby, supra note 216 , at 386.

220 Chimel v. California, 395 U.S. 752, 765 (1969).

221359 U.S. 360 (1959), overruled by Camara v. Municipal Court, 387 U.S. 523 (1967).

222 Id. at 373.

223 Id. at 372.

224387 U.S. 523 (1967). 
definitional scope of the Fourth Amendment. ${ }^{225}$ The essential purpose of the amendment, he observed, was to "safeguard the privacy and security of individuals against arbitrary invasions by government officials."226 Still, White recognized the government's need to conduct housing inspections without having to meet the onerous burden of demonstrating individualized suspicion. White responded to the pressing government interests by finding that the probable cause requirement could be met if the government demonstrated the reasonableness of its area housing inspection.

In an illuminating debate, the Camara dissenters objected to the majority's argnment because it created an "unnecessary" procedural hurdle to area housing inspections. Justice Tom C. Clark noted "that the factors the Court relies upon are the identical ones [given] for excusing warrants in Frank v. Maryland."227 Clark's observation is telling. He complained that White's examination of the governinent purposes at the apphication stage imposed the burden of requiring the government to hurdle the "legalistic facade" of obtaining a search warrant. ${ }^{228}$ Clark overlooked the point that this "legahistic facade" of demonstrating the reasonableness of the area inspection actually maintained the integrity of the separate prongs of constitutional adjudication. Whereas in Frank the Court used government purposes to define the limits of the Fourth Amendment, in Camara the Court examined these purposes to determine whether the infringements were justified. In this context, the different perspectives had a palpable effect: the burden of persuasion was placed upon the government to deinonstrate the reasonableness of its action. Over time, however, the Court has increasingly ignored the essential insight of Camara and has collapsed the definition and application prongs into one jumble. Today, these prongs are not collapsed as in Frank to demark a category, but instead in an attempt to reconcile conflicting rights and interests on a case-by-case basis.

It should be emphasized that the ad hoc formula of Camara has the potential to conform well to a balancing inethod based squarely on Madisonian premises. The error in the Court's Fourth Amendinent balancing cases is not in the inethod, but rather in how it apphes that

225 Id. at 531.

226 Id. at 528.

227 Id. at 554 (Clark, J., dissenting).

228 Id. at 554-55 (Clark, J., dissenting). 
balancing method. The Court's ad hoc balancing correctly operates at the application stage but does not allocate the burden to the government as is usually done in that second prong. The Court collects the arguments favoring rights and compares them to the government's reasons for infringing those rights: "On one side of the balance are arrayed the individual's legitimate expectations of privacy and personal security; on the other, the government's need for effective inethods to deal with breaches of public order."229 But in practice, rather than being sohcitous of individual rights by placing a thumb on the individual's side of the scales, "the judicial thumb ... . [has been] planted firinly on the law enforcement side of the scales." 230 Across a wide range of Fourth Amendment cases, the Court defers to government interests and judginents despite the infringement of the individual's right to be free of unreasonable searches and seizures. ${ }^{231}$ This majoritarian perspective has led the Court to accept some remarkable empirical conclusions regarding the effect of police intrusions on an individual's daily life. For example, in United States v. MartinezFuerte, ${ }^{232}$ in which the Court upheld border patrol checkpoint stops of vehicles away from the border without particularized suspicion, the Court observed that "the stops [at border crossing checkpoints] should not be frightening or offensive because of their public and relatively routine nature."233 This questionable assumption was accepted because the Court did not scrutinize it with any rigor.

Another good example of the Court's approach is New Jersey $v$. T.L.O. ${ }^{234}$ In T.L.O., the Court upheld a school administrator's search of a student's handbag that was conducted without a warrant and without probable cause. The student had been accused of smoking in the bathroom; the search uncovered cigarettes, rolling papers, marijuana, and written notes linking the student to sellimg drugs. Justice White, writing for the Court, balanced the student's right to privacy against the interests of the school. ${ }^{235}$ Although the Court found the student's right to privacy in her personal possessions to be signifi-

\footnotetext{
229 New Jersey v. T.L.O., 469 U.S. 325, 337 (1985).

230 United States v. Sharpe, 470 U.S. 675, 720 (1985) (Brennan, J., dissenting).

231 See Strossen, supra note 216, at 1190-91.

232428 U.S. 543 (1976).

233 Id. at 560 .

234469 U.S. 325 (1985).

235 Id. at 337.
} 
cant, ${ }^{236}$ the Court concluded that "the substantial interest of teachers and administrators in maintaining discipline in the classrooin and on school grounds"237 was greater.

A close reading of T.L.O. reveals that the balance was considered to be a close call, with the school's interest only slightly edging out the student's rights. ${ }^{238}$ It might well seem that if the burden of persuasion had been on the government, it wonld have lost. Justice Blackmun, who would disagree with this observation, criticized the majority for not making it clear that the government generally does bear a substantial burden at the application stage and that it had met that burden in this case. ${ }^{239}$ Justice Blackmun explained that the Fourth Amendment finds a search to be "reasonable only if supported by a judicial warrant based on probable cause." 240 This standard, he argued, is waived "[o]nly in those exceptional circumstances in which special needs, beyond the normal need for law enforceinent, make the warrant and probable-cause requirement impracticable."241 Blackmun's concurrence follows the spirit of Camara in advancing an ad hoc balancing strategy at the apphication stage and, at the same time, adhering to basic Madisonian principles by placing the burden squarely on the government to prove a "special need."

The Court's error in Fourth Amendment ad hoc balancing lies in its failure to adequately scrutinize the government's interests when a fundamental right is at stake. As the Court understood, the search in T.L.O. was not an unobtrusive event that did not substantially imphcate privacy concerns. ${ }^{242}$ The primcipal searched through the student's handbag and read her private correspondence. Yet in the balance, the Court merely heaped upon the scales the conflicting interests, failing to assess with any rigor the quality of the factors it was weighing.

236 Id. at $337-39$.

237 Id. at 339.

238 Id. at $339-43$.

239 Id. at 351 (Blackmun, J., concurring).

240 Id. (Blackmun, J., concurring) (quoting United States v. Place, 462 U.S. 696, 722 (1983)).

241 Id. (Blackmun, J., concurring).

242 Id. at 337-39. 


\section{CONCLUSION}

Conventionally understood, constitutional adjudication consists of two parts: a definition prong and an apphication prong. At the definition stage, the Court determines whether a constitutional right applies and, if so, how deeply the right is held. At the application stage, the Court determines whether the Constitution has been violated by assessing the governinent's justification for infringing the covered right. Under traditional Madisonian principles, these prongs are entirely separate, and indeed, if the Bill of Rights is to constitute an effective bulwark, rights cannot be defined by the majority's reasons for acting. Contrary to this model, the Court regularly imports government interest analysis into the definition prong, thus identifying the existence and parameters of individual rights by virtue of government purposes. This practice violates the most basic operating assumptions of the Constitution.

Under the conventional view, governinent action is presumptively valid. This imitial presumption gives rise to a series of shifting burdens of persuasion in constitutional adjudication. The challenger of government action first must demonstrate that a right encompassed by the Constitution has been infringed. If a deeply revered right is implicated, the government assumes the burden to justify the infringement with sufficient reasons. The strength of this argument invariably depends on the factual relationship between the government action and its stated purposes. In theory, therefore, the definition prong establishes who holds the burden of persuasion in the application stage, as well as how heavy tliat burden will be.

In practice, however, the Court regularly employs government interests analysis in its rights definition. This practice has a profound effect on constitutional discourse. By evaluating government purposes in the definition prong the Court effectively reverses the burden of persuasion for deinonstrating the factual nexus between those purposes and the complained of action. The Court reinoves the burden froin the government by using the government's purposes to define the right at stake, thus shifting the burden to the challenger who is responsible for showing that the Constitution applies in the first place.

The Court has merged the two prongs of constitutional adjudication all along the spectrum of constitutional methods. At the categorical pole, the Court uses government interest analysis to define a category's contours. The goverument's purposes are submerged in 
the Court's definition of the pertinent category, a definition for which the challenger ultimately bears the burden. In the array of balancing strategies the Court has also transposed Madisonian principles. In definitional balancing the Court uses government interests to lighten the individual's side of the scales. This practice has the effect of shifting away from the government any obligation to deinonstrate the factual justification for its infringeinent of an individual right. The right is defined as not existing by virtue of the asserted government purposes. Similarly, in multitiered balancing contexts the Court einploys governinent interests to dilute the definition of rights, rather than scrutinize those interests to deternnine whether they justify the infringeinent of defined rights. Finally, in ad hoc balancing, the Court does not so inuch misallocate the burden of persuasion as simply fail to allocate it at all. Ad hoc balancing proceeds on the assuinption that a constitutional right is implicated but often succeeds in deferring to the governinent's stated needs.

The Court's failure to keep the two stages of constitutional adjudication separate is imdicative of a deep crisis confronting constitutional theory. The Court's responsibility for mediating the inherent conflict between individual rights and inajority will means it should not greatly privilege one fundamental principle over the other. Although the Court describes its inethodology as either neutral or with himited majoritarian leanings, its methodology behes this description. The merger of the two prongs of constitutional adjudication achieves a significant victory for inajoritarian forces. Majoritarianisin has prevailed not through a frontal assault, however, but by stealthily moving inside the walls of the Bill of Rights to weaken individual liberties from within. 